\title{
جريمة التسليم للعدو - دراسة مقارنة -
}

\section{م. بهيیى حمّود مراد الوائلي \\ كلية القانوز / جامعة واسط \\ الغلاصة}

جريمة التسليم للعدو من الجرائم العسكرية التي قد تعصف بوجود الدولة واستقلالها لما يترتب عليها من فقدان كلي أو جزئي لإقليم

الدولة ، ولما ير افقها من جر ائم قتل وسرقة وتخريب البنية التحتية للبلاد، بل هي تهديد للنظام السياسي القائم في الدولة ، وتتكون هذه الجريمة

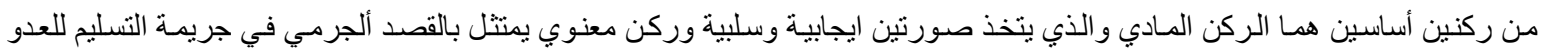

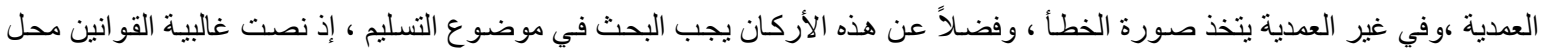
المقارنة على شرطين مفترضين لتحقق هذه الجريمة تمنلت بمحل جريمة التسليم والثاني يشمل عدم استنفاذ جميع وسائل الدفاع لدى العسكريين

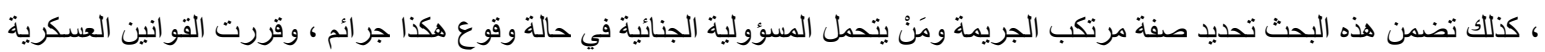
محل المقارنة عقوبة لمرتكب هذه الجريمة ، وتباينت هذه القو انين في موقفها من الجز اء المقرر لجريمة التسليم للعدو.

\section{Summary:-}

Extradition crime to enemy military crimes plaguing the existence and independence of the state, that result from them of total or partial loss of the territory of the state and the accompany her from killing and stealing and sabotaging state althadih infrastructure but threatens its independence and this crime consists of tow basic pillars of physical crime taking corner tow and positive and negative mental element be subdivided the crime tow mayor and unintentional comparison shop laws required conditions at the crime as well as the perpetrator and the perpetrator punished by military laws that crimes.

أولاً : فكرة البمث :

تُعذ جريمة التسليم للعدو من الجر ائم العسكرية والتي لها أهمية كبيرة في قوانين العقوبـات العسكرية كافة، القديمة منها و الحديثة ، لمـا تنطوي عليه هذه الجرائم من خطر ولمـا يترتب على ارتكابها من نتائج جسيمة يمكن أن تهدد كيان الدولة واستقلالها وسلامة أر اضيها. ومن الطبيعي أن تحظى جريمـة التسليم للعدو بنصـيب مـن هــا الاهتمـام، إذ تكمـنْ خطورتهـا بـالجر ائم الخطيـرة التـي تر افـق ارتكابهـا كالقتـل و السـرقة و الاغتصاب و التخريب الذي تتعرض لله المباني و الممتلكات العامـة و الخاصـة على السواء، ممـا بؤدي إلى إثـاعة الفوضى و الدمار نتيجة الانفلات على القانون، فضلاً عن أن ارتكابها قد يكون من الأثر، بحيث يؤدي إلى إسقاط النظام القائم في الدولة أو إلى انفصال جزء من إقليم الدولة، لذا نجد أن المشرع العراقي قد عاقب على هذه الجريمة في قانون العقوبـات العر اقي العسكري رقم (9 (1) لسنة V . . ب المعدل. و على الرغم من خطورة هذه الجريمة، فإنها لم تتل الاهتمام الكافي من فقه القـانون الجنائي، فلم أجد من الكتب القانونيـة التي تعرضت لدر اسة هذه الجريمـة إلا القليل جداً بـل ولم تعالجها بشكلٍ منفرد و إنمـا بحثتها باعتبار هـا جزءً من جر ائم أخرى.

\section{ثانيك: أهمية البهش}

وتمكن أهميـة هذا البحث في دراسـة جريمـة التسليم للعدو ، ومـا لها مـن تـأثثر سلبي على النظـام العسكري والدولة على حلٍ سو اء ، لأن هيبة الدولـة تكمنْ في المحافظة على أر اضيها، و الحفاظ على حق 
الحياة وباقي الحقوق الأساسية لمو اطنيها ،هذه من جهة ومن جهة أخرى تكمن أهمية البحث في تحديد مَنْ هو المسؤول عن سقوط أر اضـي الدولة بيد العدو واحتلالها كمـا حصل الآن في العر اق من احتلال لمحافظتي الموصل وصلاح الدين وسقوطها بيد عصابات داعش الإرهابية دون قتال .

ثالثا: مشكالة البهث أن مشكلة البحث تدور حول أن هذه الجريمة ، موجودة بشكلٍ من الأشكال في غالبيـة قوانين العقوبات العسكرية للاول ، ولكن هذه التشريعات ، اختلفت في تجريمها وهذا ماسنر اه خـلال البحث من موقف قو انين

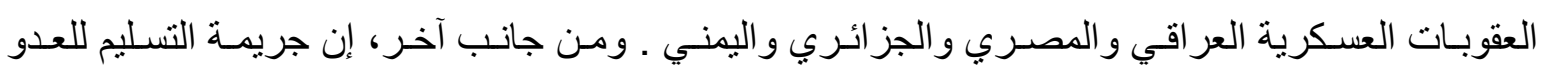

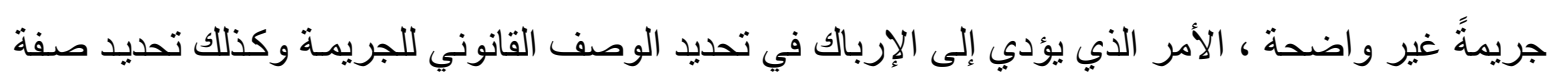
مرتكبها، إذ يلحظ أن قانون الأحكام العسكرية المصري رقم (Y0) لسنة 979 (19 المعدل قد أدرجها في الباب

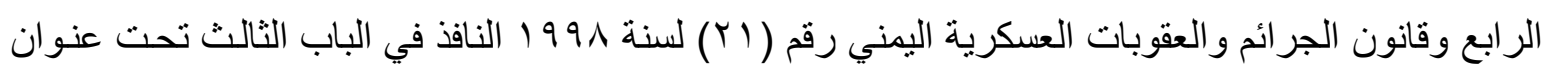

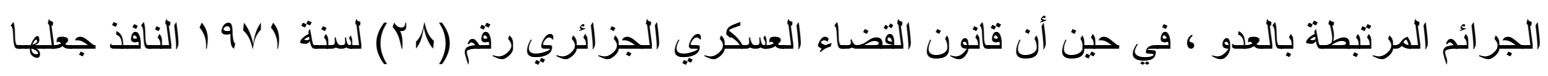
في القسم الثاني ضمن جر ائم الخيانة والتجسس و المؤامرة العسكرية ، أما في العراق فقد بوبها قانون العقوبات العسكري رقم (9 (1) لسنة V . . . المعدل في الفصل الثالث ضمن الجر ائم الماسـة بـأمن الدولة ولكن قانون عقوبات قوى الأمن الداخلي العر اقي رقم (ع () لسنة م . . ب أثنار إليها في الفصل الثالث تحت عنوان جر ائم

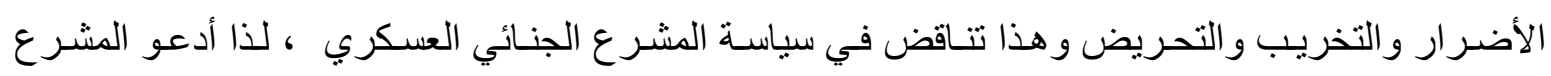
الجنائي العر اقي إلى إفراد فصل خاص بهذه الجريمة تحت عنوان جرائم التسليم للعدو في القانونين آنفي الذكر

\section{رابهك: منهمية البمث}

سأعتمد في هذا البحث منهجاً تأصيلياً تحليلياً مقارناً في الوقت ذاته ، إذ سأسلك المنهج ألتأصيلي من

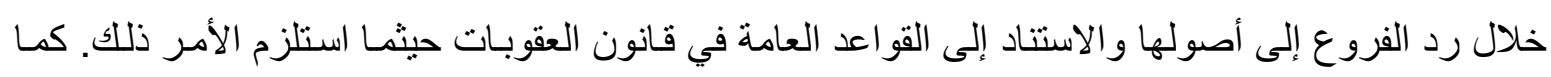
سيكون المنهج تحليلياً من خلال دراسة وتحليل النصوص القانونية المنظمـة للموضوع وكلو وكل مـا قيل من آراء

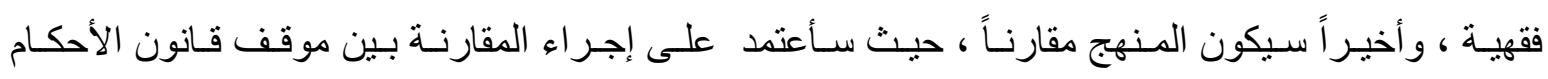

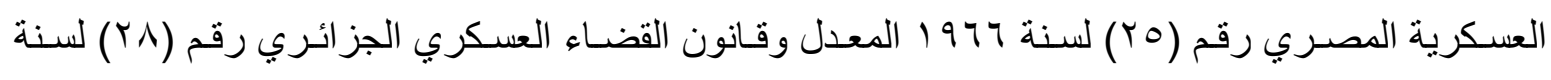

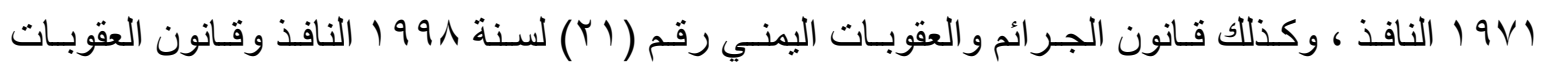
العسكري العر اقي رقم (9 (1) لسنة V . . . المعدل ، و التطور الذي طر أ على أحكام هذه القوانين المتعلقة بجريمة التسليم للعدو ، وذلك للتعرّف على القانون ذو النصوص الأكثر فعالية في معالجة هذه الجريمة .

\section{خامسك: خطة البمث}

قشّمتُ البحث على مبحثثين ، خصصت المبحث الأول إلى ماهيـة جريمـة التسليم للعدو و على ثلاثـة

مطالب ، أثنرتُ في الأول إلى مفهوم جريمـة التسليم للعدو ، وفي المطلب الثاني إلى موضـوع التسليم ،

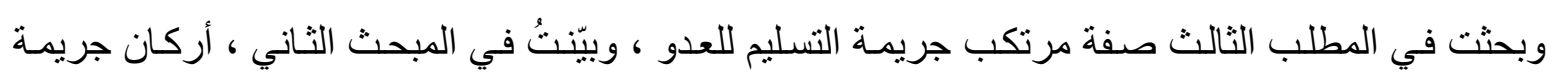
التسليم للعدو و عقوبتها و على ثناثنة مطالب ، تتاولت في الأول الركن المادي للجريمـة، وعرّجت في الثناني 
على الركن المعنوي للجريمـة ، ووضـتُ في المطلب الثالث عقوبـة جريمـة التسليم للعدو، و أنهيث البحث بخاتمة تضمنت أهم النتائج و المقترحات ، وكالآتي :

\section{المبمث الأول- ماهية جريمة التساليم}

لمعرفة حقيقة جريمة التسليم للعدو ينبغي التعرّف على ماهيـة هذه الجريمـة ، ولفهم الماهية يقتضـي

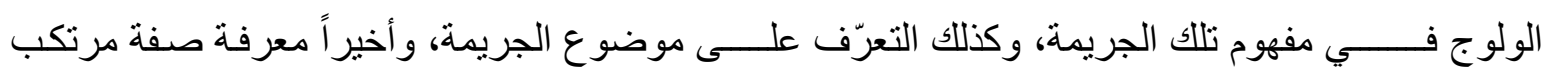
تللك الجريمة ، لذا سأقسم هذا المبحث على ثلاثة مطالب كالآتي:

الإطاب الأول- مفهوم جريمة التسايميم

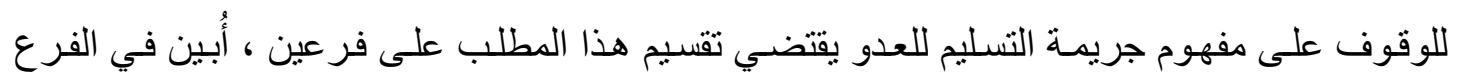

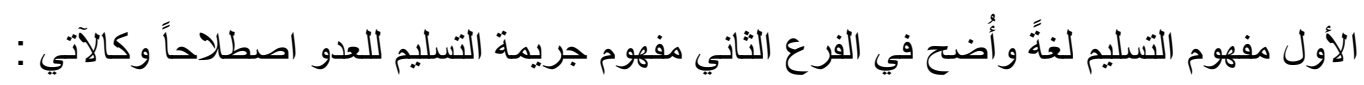

\section{الفرع الأول- هفموم جريمة التسليم لغة}

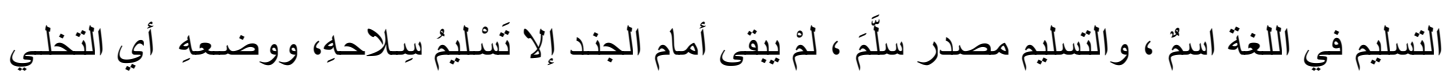

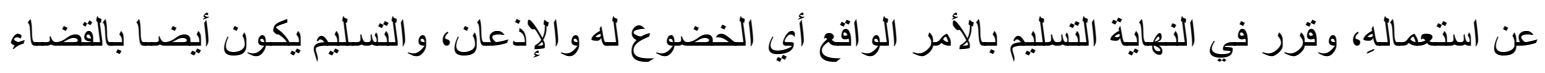

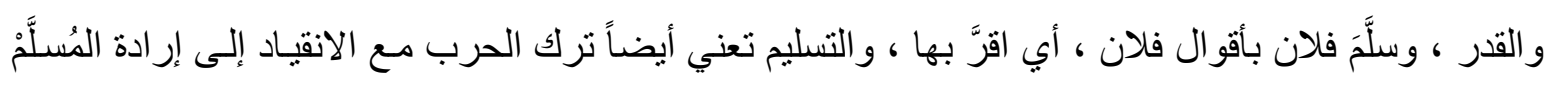

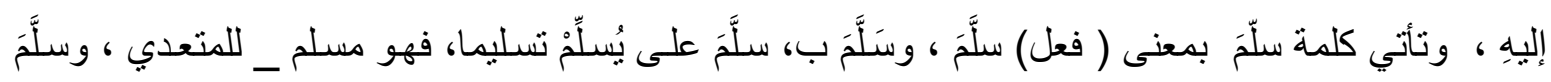
الثخص إذا استسلم أي انقاد بدون مقاومة(') .

\section{الفرع الثاني- مفهوم جربمة التصليم اصطلامكا}

ير اد بالتسليم وضع الثيء في حيازة العدو أو تمكينه من الاستيلاء عليه ، ويكون التسليم المقصود في

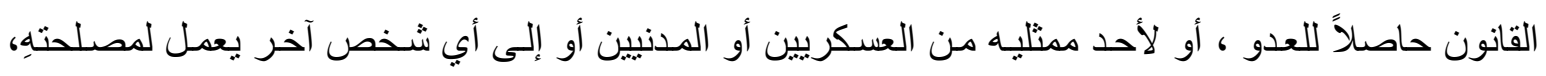

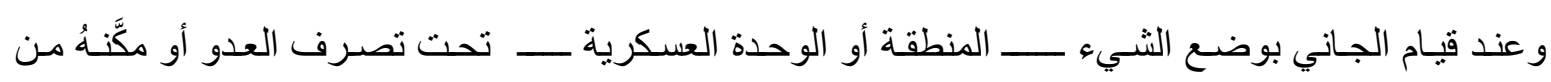

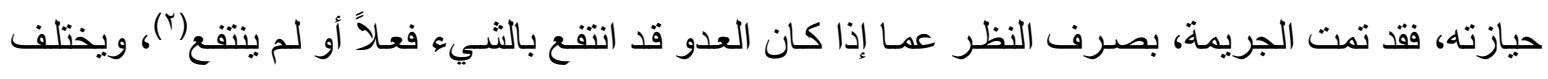
التسليم عن التسهيل، إذير اد بالأخير كل وسيلة تتسبب في التسليم ، فقد تكون من قبيل التخريب المعنوي ، بإذاعة بياناتِ أو إنثاعاتِ كاذبة أو مغرضة تثير الفزع و الهلع بين الجنود، وتؤثر في معنوياتهم، وكذللك يعني تعييب أو تعطيل المعدات الحربيـة، أو تحريض الجنود على الفرار ، ولو أن كل فعل من هذا القبيل يعده

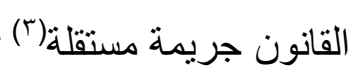

\section{الإلبب الثانبي- موضوع التسبيم}

جريمة التسليم للعدو من حيث كونها كياناً قانونياً تتألف ـوفقاً للر أي الراجح - من ركنين أساسيين هما

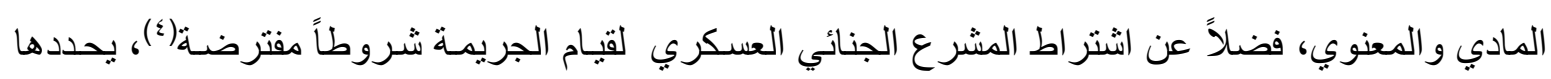

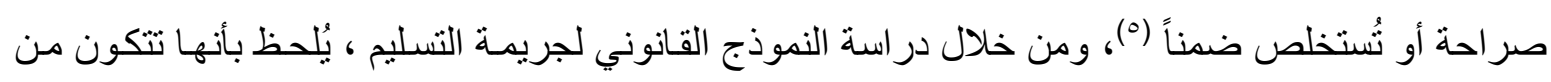

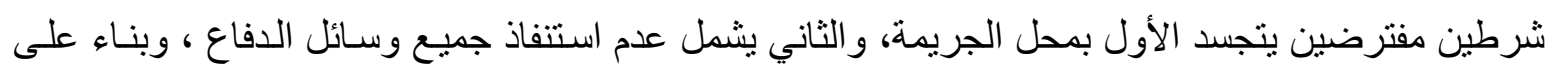
ذلك سأقسّم هذا المطلب على فرعين التاليين: 


\section{الفزع الأول- همل جريمة التسليم}

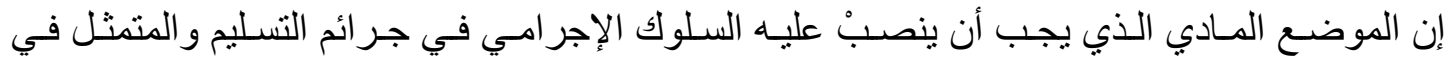
السلوك الايجـابي أو السلبي ، هو الموقع أو المحل الذي يختص الجاني بالمحافظة عليه (ج)، فقد بيّن قانون

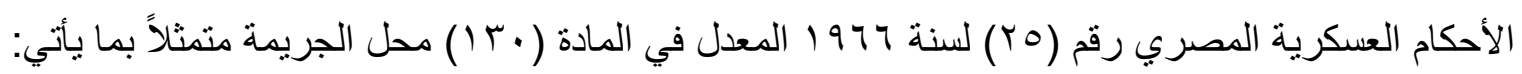
ا - ترك أو تسليم حامية أو محلاً أو موقعاً أو مركزاً . r- إلقاء أسلحته أو ذخيرته أو مهاماته أو تجهيز اته أمام العدو .

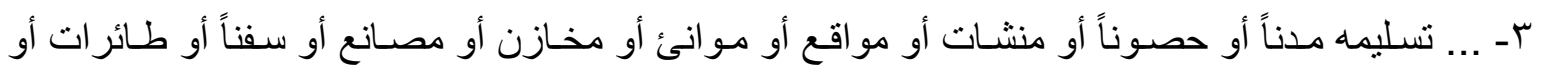

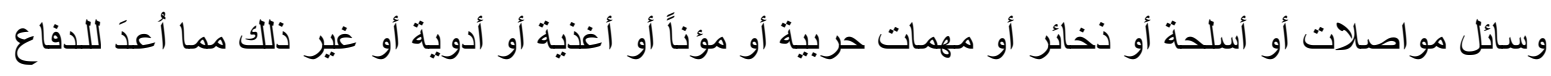
أو مما يُستعمل في ذلك. وجاءت المادة (0 10) من قانون الجرائم والعقوبـات العسكرية اليمني رقم ( اYY) لسنة 1991 النافذ بنص مشابه لما جاء به المشرع الجنائي العسكري المصري ـ و أشنارت المادة (YV9) من قانون

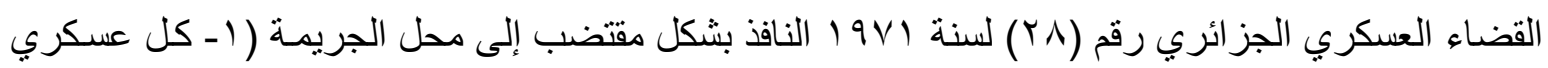
يُسلِّم للعدو أو لمصلحة العدو ، الفرقة التي هي في إمرته أو الموقع الموكل إليه أو مئونـات الجيش أو خر ائط

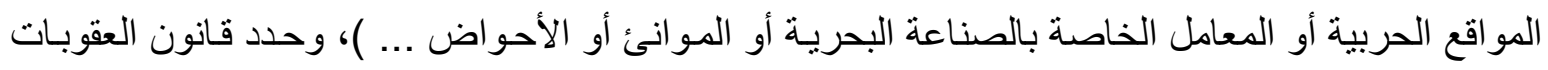

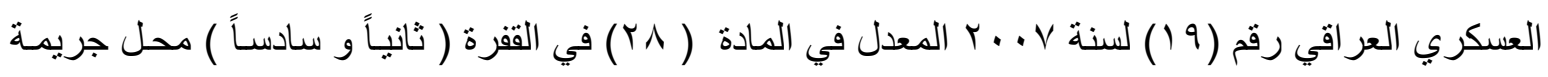
التسليم كالآتي :

ثانياً : ... موقعاً أو مكاناً أو مخفراً أو حاميـة أو حرسـاً خفراً ... المعامل العسكرية المختصـة بالعتـاد وأدوات الحرب و المصانع ومخازن العينة وأدوات المخابرة ووسائل التتقل... سهل استيلاء العدو على قسم من القوات المسلحة)،( سادساً: ... تسليم قوة نهرية أو بحرية أو جوية ... أو تسليم طاقمها.... ) من خلال النصوص المتقدة أود أن أُبين ملاحظة مههـة ، أن المشرع الجنائي العسكري المصري قد أورد هذا التعداد ليس على سبيل الحصر ، إنما قصد به جميع الأماكن التي يشـلها العسكريون ، وهذا ظـاهر

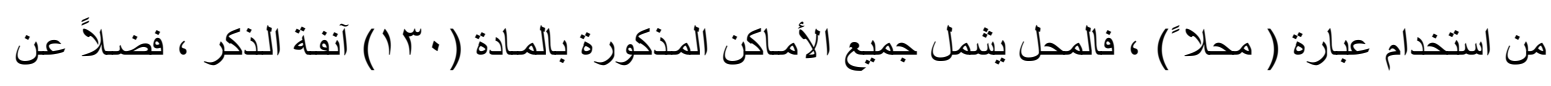

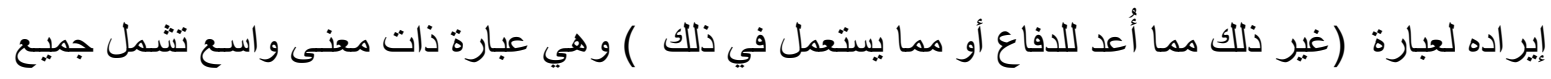

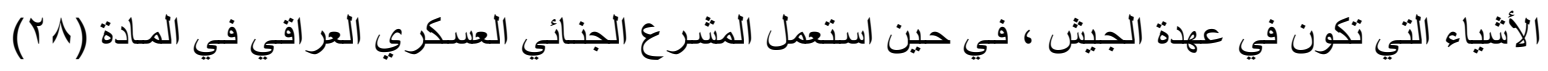

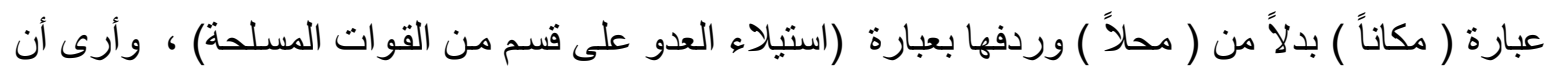

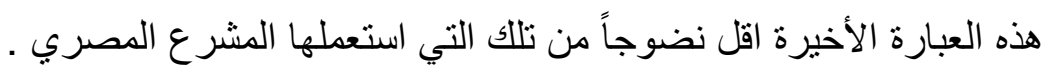

\section{الفرع الثاني- عدم استنفاذ جميج وسائل الدفاع وما تقتضيه واجبات الوظليفة}

الثـرط المفترض الثاني في جريمـة التسليم الذي نصّـت عليـه القوانين محل المقارنـة هو أن يستنفذ

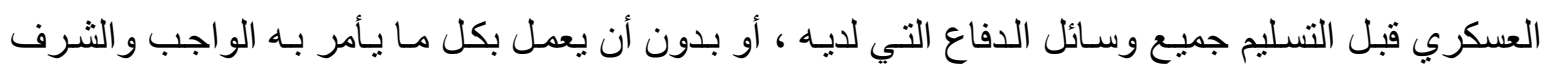
العسكري ، ويُفسِر هذا الثرط بـأن علــــــى الجندي في سـاحة القتال أن يواجه خطر الموت حتى استنفاذ

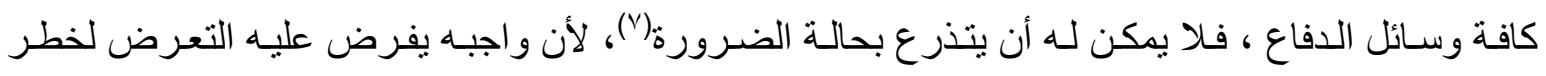


الموت ، ولكن متى استتفذ وسائل الدفاع ، فإن المحافظة على أرواح ما بقي من الجنود ، يقتضي التسليم وفي الحالة الأخيرة ، لا يكون القائد مخطئًا إذا أقدم على التسليم.

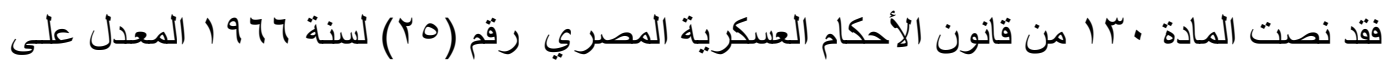
هذا الثـرط بقولها ( ... بدون أن يستنفذ جميع وسـائل الدفاع التي لديـه أو بدون أن يعمل بكل مـا يـأمر بـهِ الو اجب و الثرف... ) ، وجاء قانون الجرائم و العقوبـات العسكرية اليمني رقم ( (Y) لسنة م9919 في المـادة

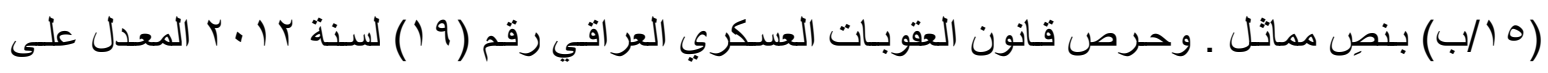
النص على هذا الثرط في أكثر من موضع ، فقد نصت المـادة (^^) الفقرة ( رابعاً) (... قبل أن ينفذ كل مـا

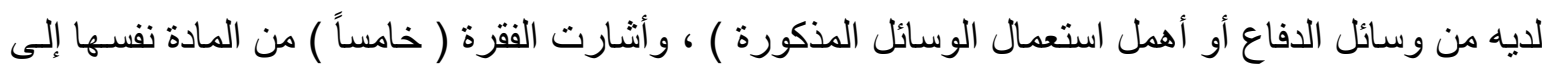
هذا الشرط ( ... من دون أن يقوم بما تقتضيه واجبات وظيفته ) ، وجـاءت الفقرة (سادساً ) من المسادة أعلاه

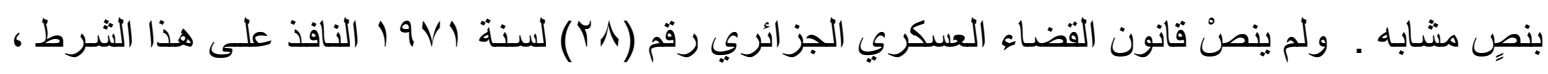

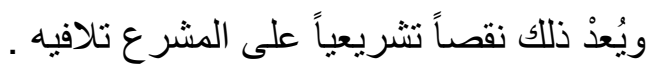

\section{الإلبب الثالث- صفة مرثكب البهريمة}

تشترط القو انين العسكرية في مرتكب الجريمة أن يكون عسكرياً مكلفاً بالدفاع عن وحدته في زمن الحرب ومن ثم جرت غالبية التشريعات على الإكتفاء بالصفة العسكرية والقيادة الفعلية. فقد حددت المسادة

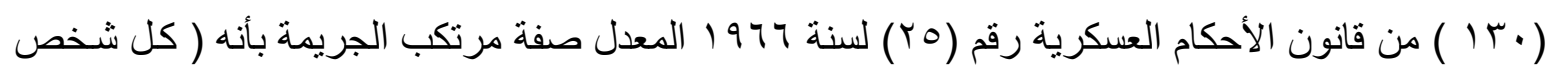

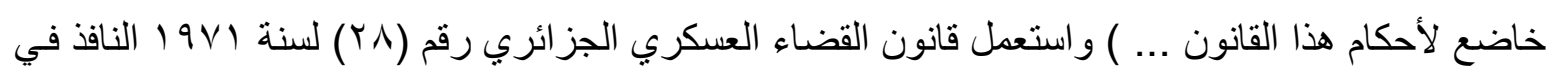
المـادة (YV9) مصطلح ( كل عسكري .... ) ، ولم يشترط قانون الجر ائم و العقوبـات العسكرية اليمني رقم

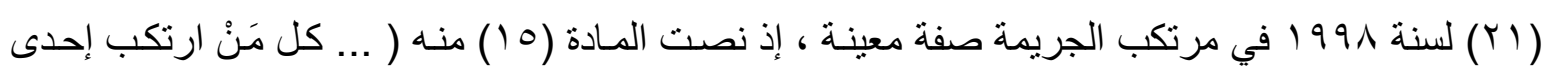

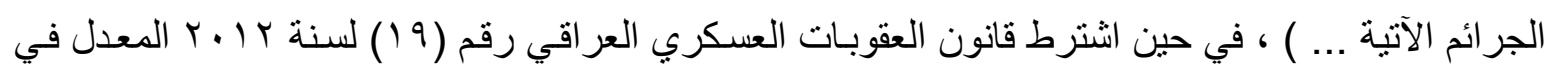

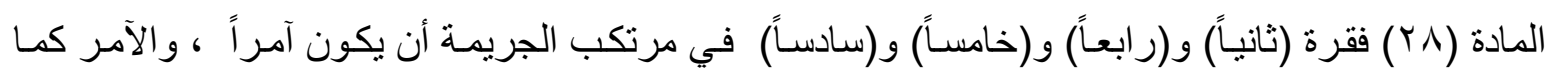
عرَّفتهُ المادة (1/ خامساً) من القانون نفسه بأنه ( الثخص الحائز سلطة الإمرة باعتبار نفوذ الأمر ).

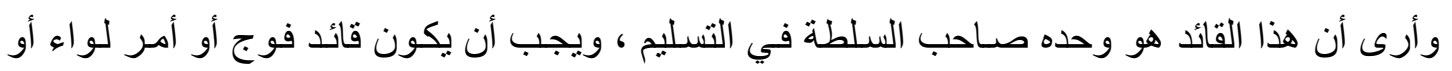

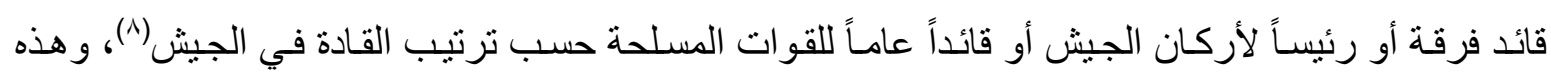
العبارة المستعملة فيها نوع من التحديد ، مـع أن الواقع قد يفرض أحياناً أن تُولى القيادة شخصٌ غير القائد

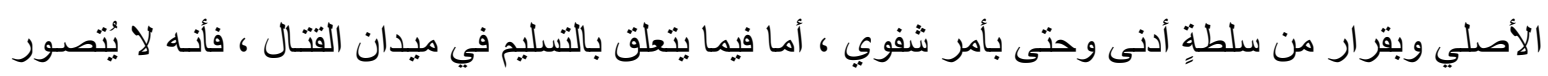

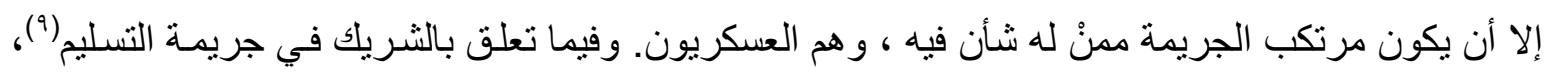

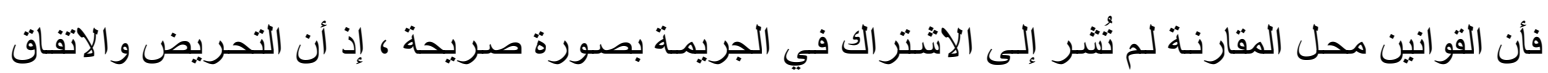
و المساعدة التي أنشارت لها هذه القو انين تكّون جرائم مستقلة لها عقوباتها الخاصة بها غير جريمـة التسليم(·'(')،

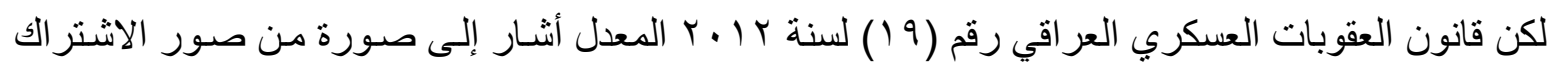

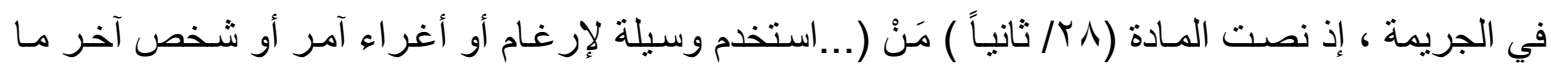


على أن يترك أو يسلم ماتتطلبه المو اقف العسكرية موقعاً ... ومَنْ سبب أو سهل استيلاء العدو علـــى قسم

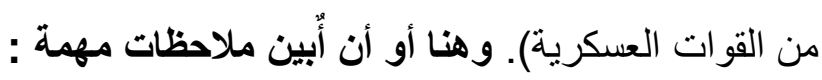

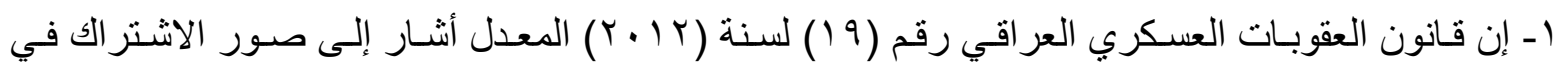

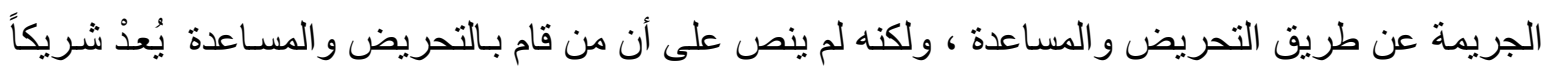

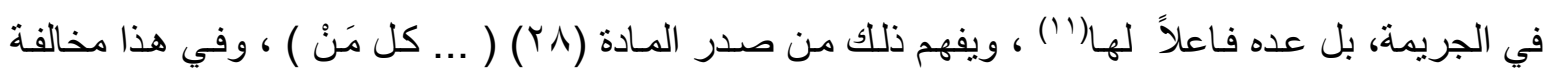

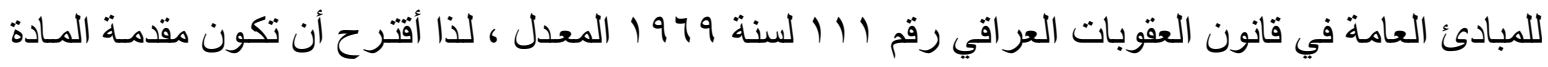

$$
\text { (Y^) كالآتي ( ... كل مَنْ ساهم بوصفه فاعلاً أو شريكاً...). }
$$

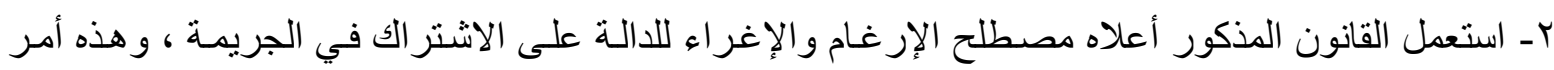

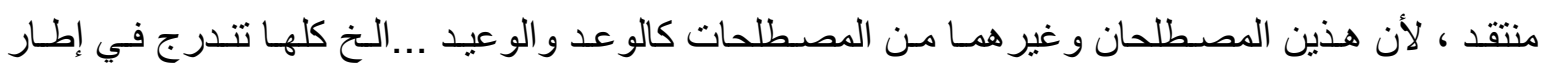

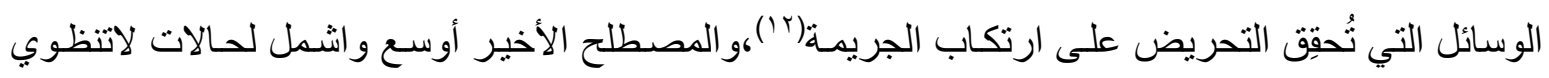

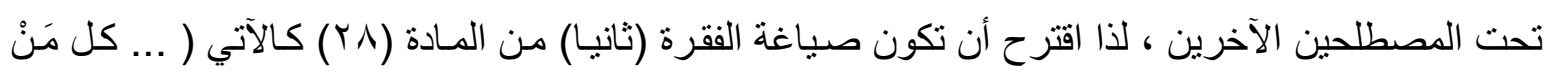

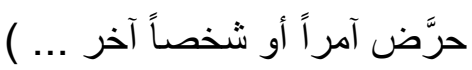

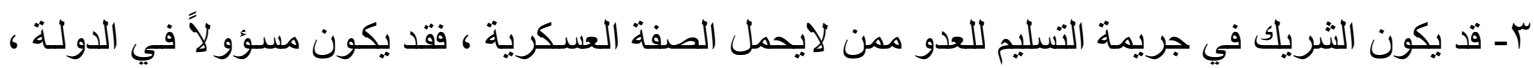

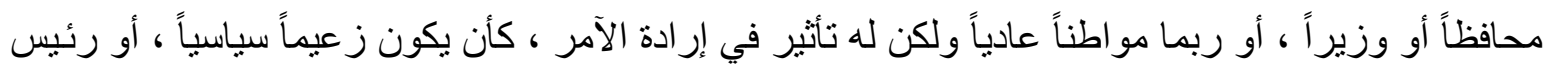

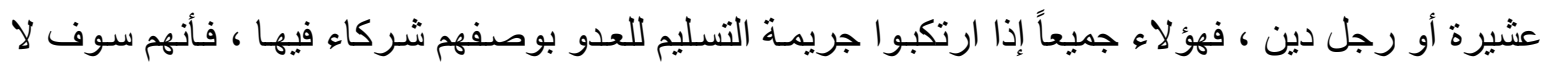

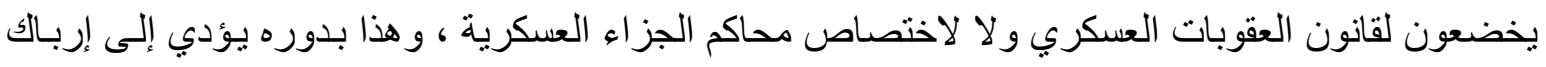

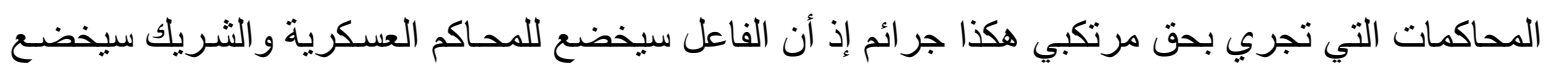

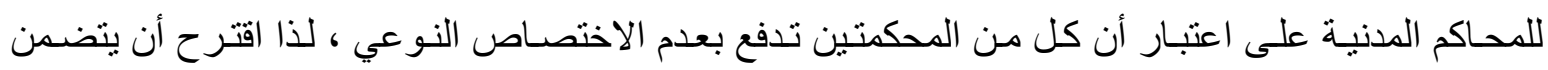

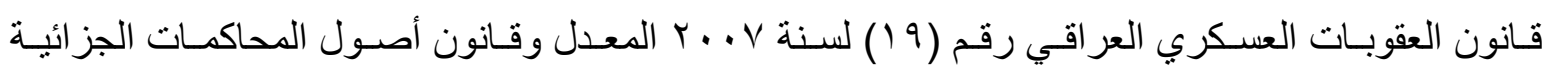

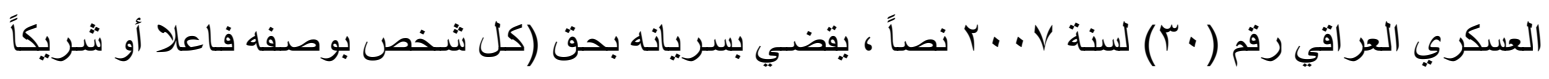

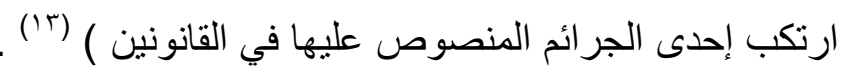

\section{المبمث الثاني- أركان جريمة التسليم وعقوبتها}

جريمة التسليم للعدو شأنها شأن غالبية الجرائم يشترط لقيامها تو افر أركانها المتمثلة بالركنين المادي

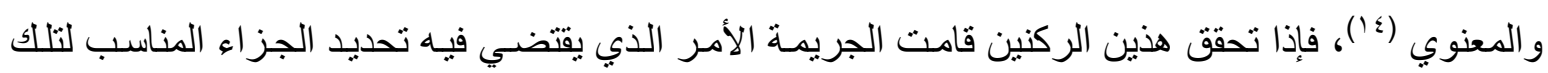

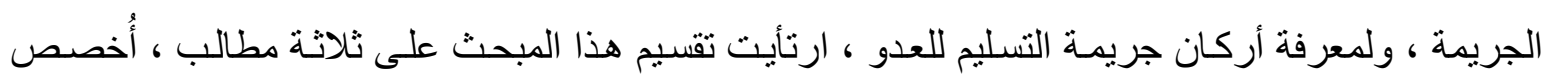

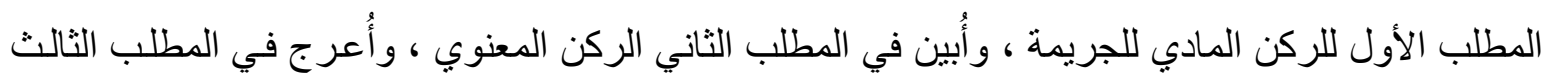

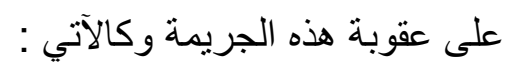

\section{المبلب الأول- الركن المادي}

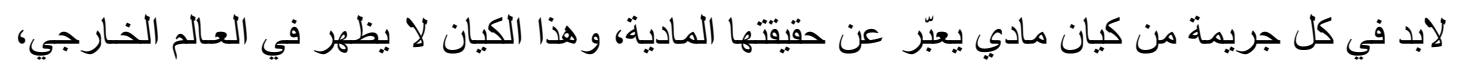

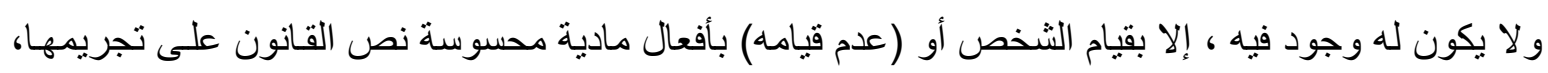

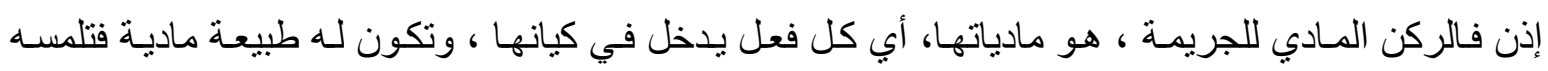




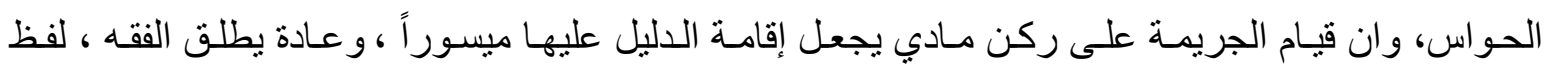
(النشاط) على الفعل الذي يأتيه الإنسان ويدخل في تكوين الجريمة(10) ، ولكن ذهب البعض إلى استعمال لفظ

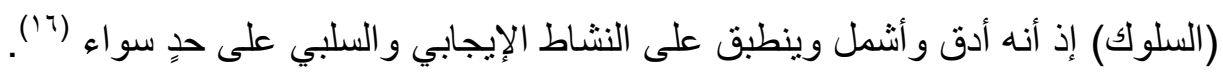
أن جريمة التسليم شأنها شأن أغلب الجرائم ، يتوجب لقيامها تو افر أركانها ، وأولها الركن المادي ، ويكون على صورتين: ايجابيةِ وسلبية.

ففي الصسورة الأولى يتمثل الركن المـادي ، بفعل إيجـابي يرتبط بنتيجةٍ غير مشروعة، وهي سقوط الموقع في يد العدو ، وقد حدد المشرّع هذا السلوك في التسليم للعدو ، أي تسليم الموقع للعدو ، ففعل التسليم

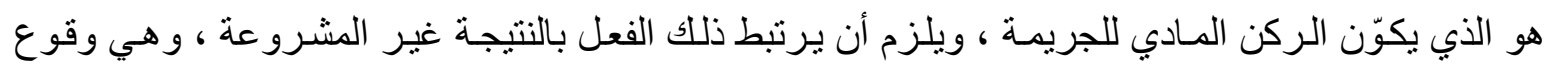

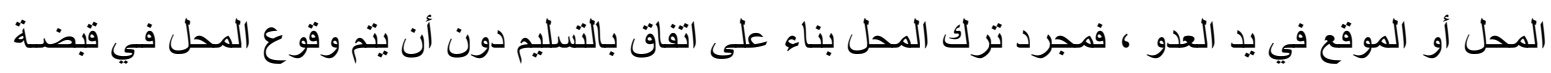

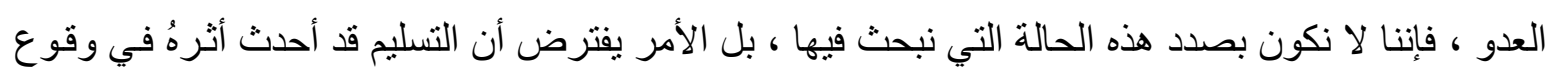
المحل في بد العدو.

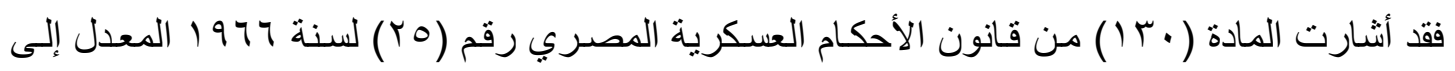

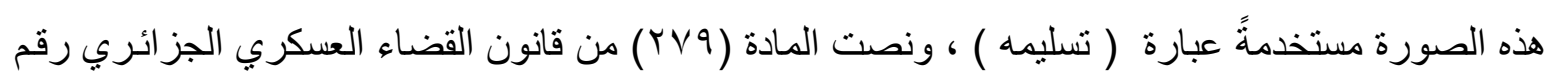

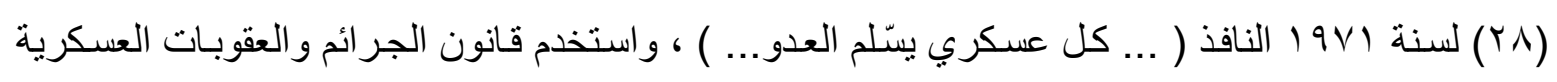
اليمني رقم (Y) لسنة 991 (1 في المادة (0 (1) منه عبارة ( ... تسليمه ... ) و هي ذاتها المستعملة في القانون

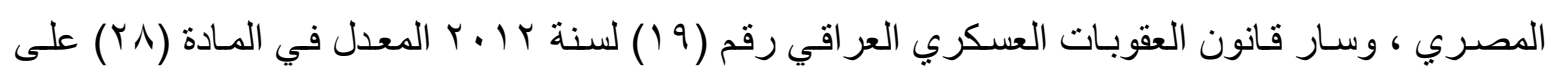
ذات النهج .

أما الصورة الأخرى للركن المادي فتتمثل في اتخاذ موقف سلبي ، من خلال ترك الموقع الذي يتواجد

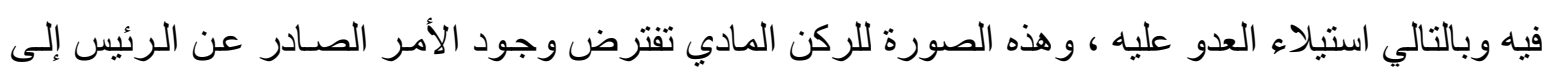

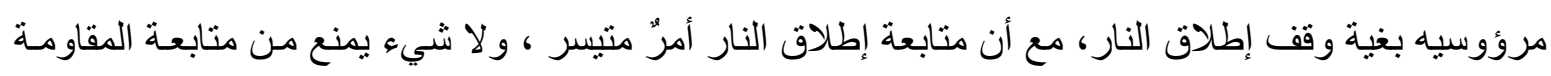

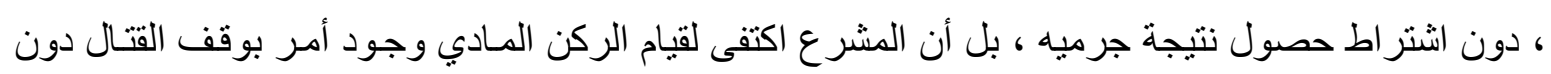

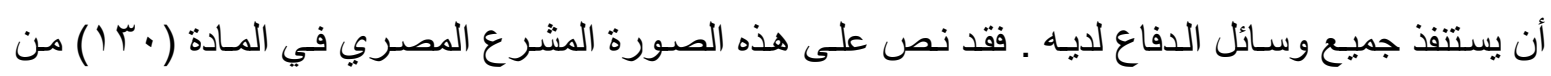

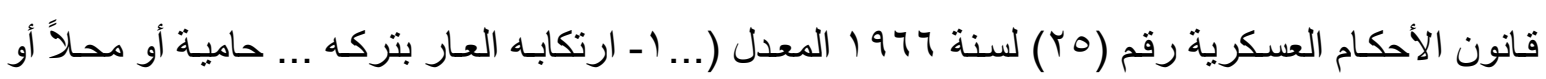

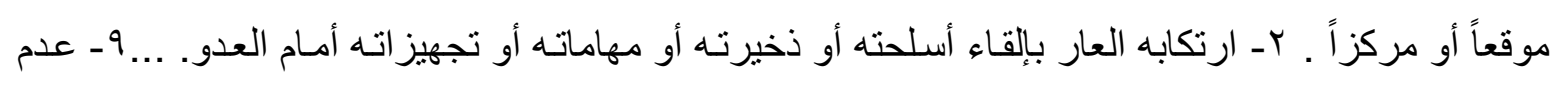

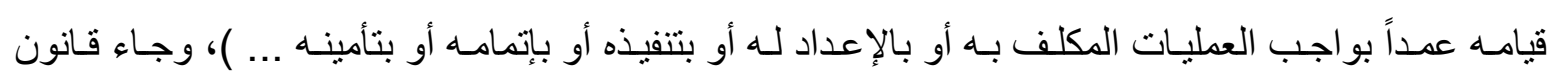

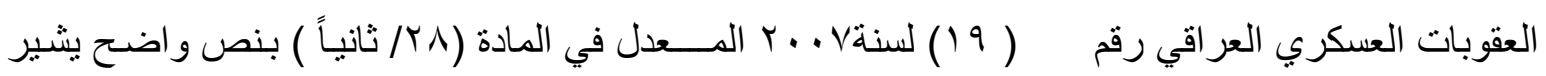
إلى هذه الصورة (... ثانياً : ترك .... إلى العدو ... موقعاً أو مكاناً أو مخفر اً ... )

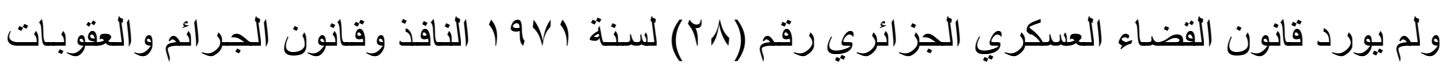

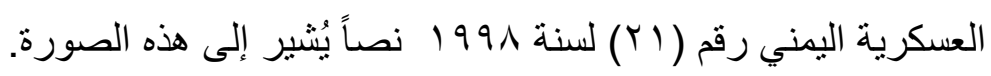




\section{المباب الثاني- الركن المعنوي}

لا يكفي لقيام الجريمة سواء كانت ايجابية أم سلبية قانوناً أن يقوم الفاعل بارتكاب الفعل المـادي فيها ، و إنما يلزم أيضاً تو افر رابطة نفية بين الفعل وماديات الجريمـة يطلق عليها الركن المعنوي ، وهذا الركن يفترض وجود علاقة نفسية بين مرتكب الفعل غير المشروع و عمله ونتيجته الضـارة ، تكون ناتجـة عن نيته الآثمة المبيتة و إر ادته واختياره الحر في اقتر اف الجريمة، فهو يعلم أن العمل الذي يقوم بـه غير مشروع وان

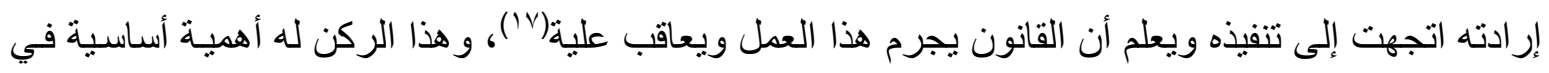
النظرية العامة للجريمة ، فالأصل انه لا جريمة بغير ركن معنوي فهو سبيل الثارع إلى تحديد المسؤول عن

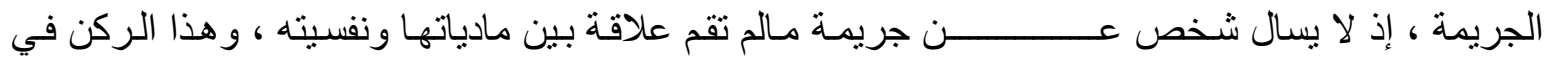

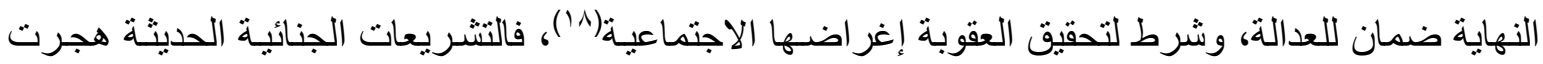
الوجهة السائدة في التشريعات القديمة التي كانت تعاقب على الفعل ونتائجه الضـارة ، وتوجب نو افر عناصر

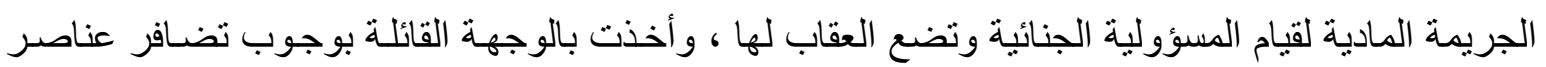

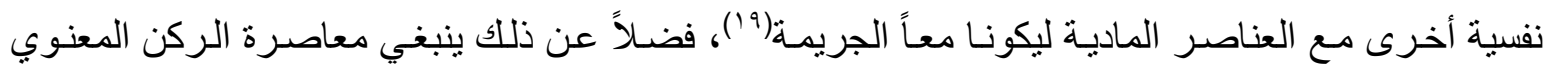
للنشاط الإجر امي للجريمة، ويتمثل الركن المعنوي في الجرائم العمدية بالقصد ألجرمي أو الجنائي ، في حين يكون بصورة (الخطأ) في الجرائم الغير عمدية(·r) .

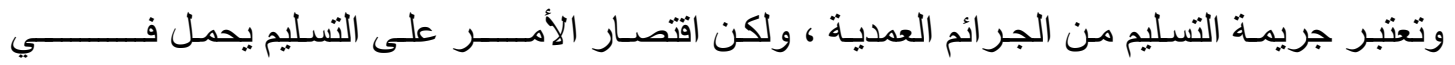
طياته وجهان ، الوجه الأول و هو القصد ، و الوجـه الثاني وهو الخطأ، فقي الأول يشترط لتحقق المسؤولية

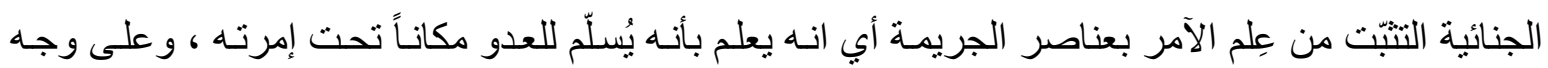
الإضـر ار بدولتهه وبقو اتها المسـلحة، وإذا انتفى العلم بأحد هذه العناصـر لايكون الآمـر مسئو لا عن جريمـةٍ

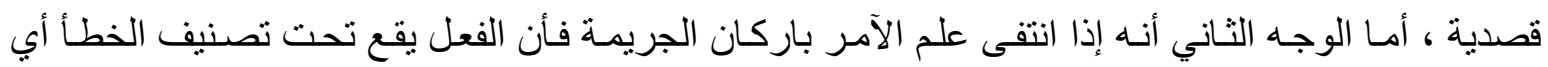

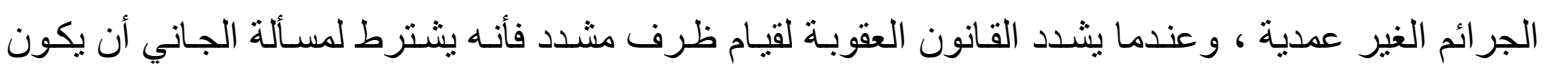

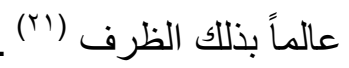
وقد بينت القوانين العسكرية موضوع المقارن الجرائم العديـة التي يتو افر فيها القصد ألجرمي لدى

مرتكبها (r)

و أشنار قانون الأحكام العسكرية المصري رقم (Y0) لسنة ج49 197 المعدل الى جرائم التسليم التي تتخذ

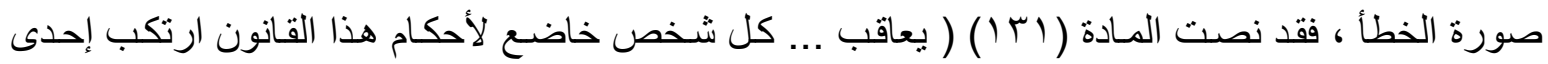

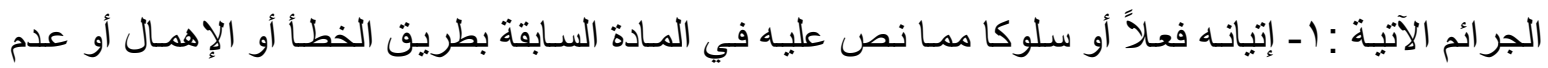

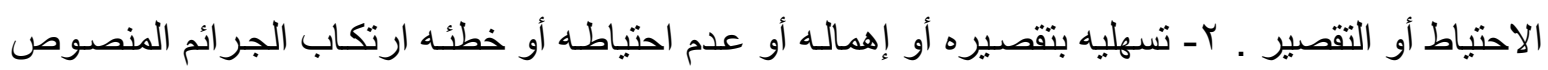

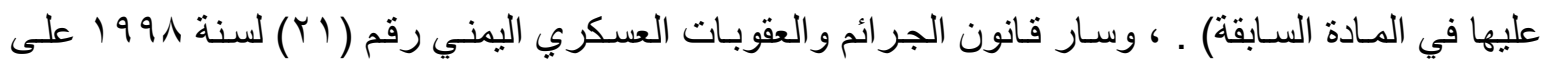
ذات النهج ، إذ نصت المادة (7 (1) ( يعاقب ... كل شخص خاضع لأحكام هذا القانون ارتكب إحدى الجرائم

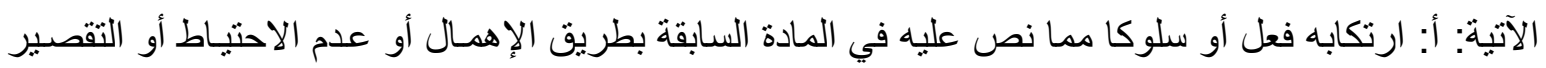
بتسهيله ارتكاب الجرائم المنصوص عليها في المادة السابقة بتقصيره أو إهماله أو عدم احتياطه) . 
ونصنَّ قانون العقوبات العسكري العر اقي رقم (9 ( ) لسنة V . . . المعدل على جر ائم الخطأ في جريمـة

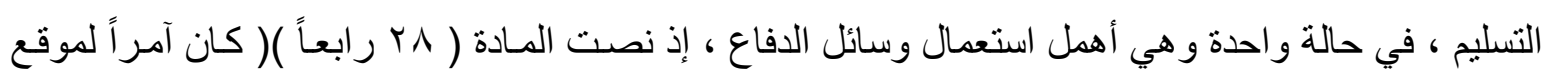

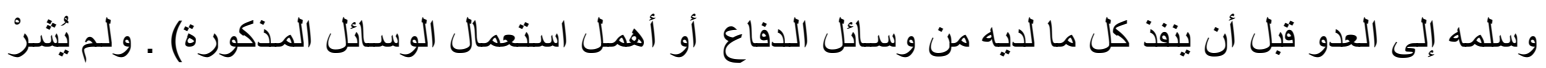

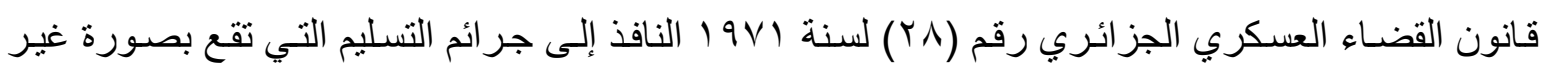
عمدية.

\section{الإhلب الثالث- العقوبة}

العقوبة بالمعنى الإصطلاحي هي جز اء يوقع باسم المجتمع ، تنفيذاً لحكم قضـائي لمن تثبت مسؤوليته

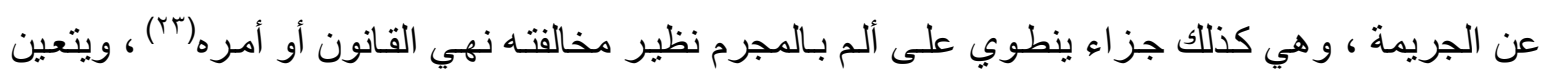
وجود تناسب بين العقوبة المطبقة وجسـامة الجريمـة من جهة، وخطيئة المجرم من جهة أخرى، فكلمـا كان الضرر الذي ألحقته الجريمة جسيماً كانت العقوبة شديدة، ومن ناحية أخرى يجب أن يكون هنـاك تناسب بئه بين العقوبة وجسامة خطيئة المجرم، فالعقوبة التي تفرض على الجاني عندما يرتكب فعله بوصف القصد أشد من العقوبة التي تفرض عليه بوصف الخطأ ، و التناسب بين العقوبة وجسـامة الجريمـة يبرز معنى الجز اء العـادل

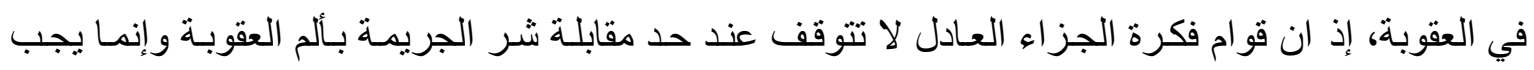

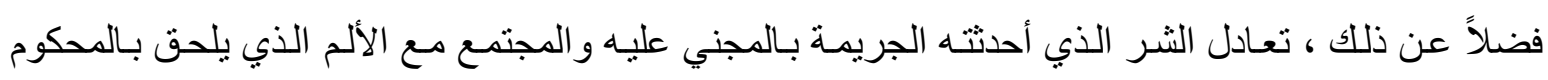

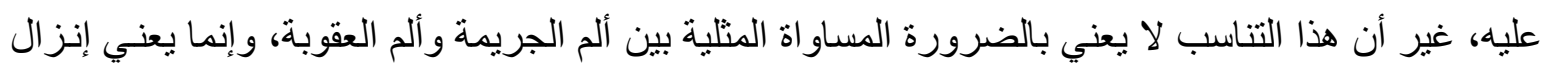
إيلام بالجاني يتناسب والضرر الذي أحدثته الجريمة ولو لم يمس هذا الإيـلام ذات الحق الذي وقعت الجريمـة

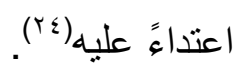

نص المشـرع المصـري في قـانون الأحكام العسكرية رقم (Y0) لسـنة 1977 المعدل على عقوبـة جريمة التسليم للعدو بشكل متدرج ، إذ فرّق في العقوبة بين الجريمة التي تُرتكبْ بطريق العمد عن تلك التي

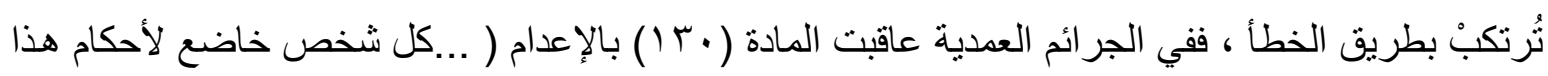
القانون ارتكب إحدى الجر ائم الآتية ـ ـ ـ ارتكابه العار بتركه أو تسليمه حامية أو محلاً أو موقعاً أو مركزاً .

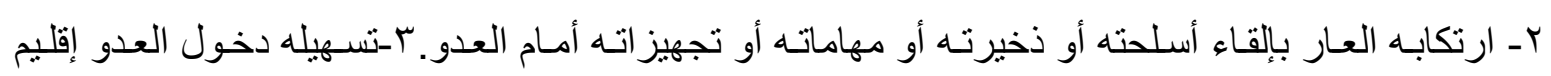
الجمهورية أو أية أقاليم للاولة عليها سيادة أو سلطان أو تسليمه مدناً أو حصونا أو منشات أو مواقع أو موانئ أو مخازن أو مصانع أو سفناً أو طائر ات أو وسائل مو اصـلات أو أسلحة أو ذخدائر أو مههـات حربيـة أو مؤنـا

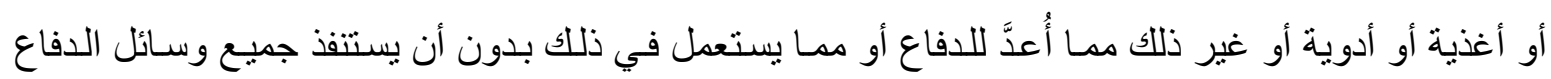

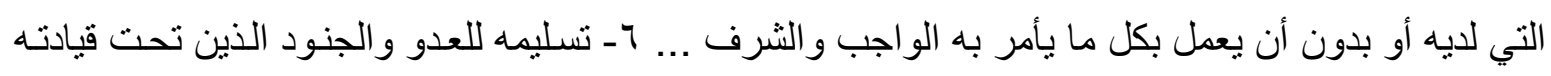

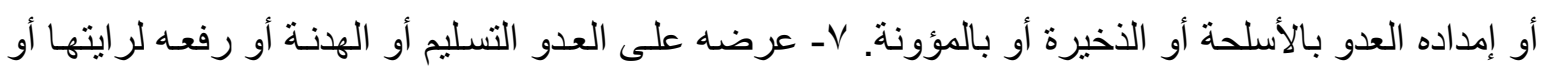

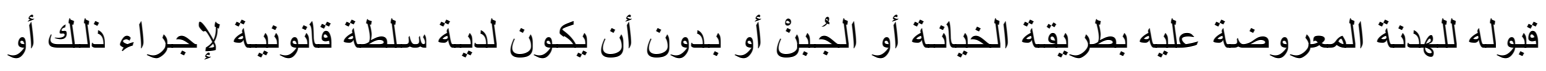
بدون أمر صريح ... ) ، وجرّمَ القانون المذكور أعلاه ، جرائم التسليم التي تقع بصورة غير عمديه ولكنه

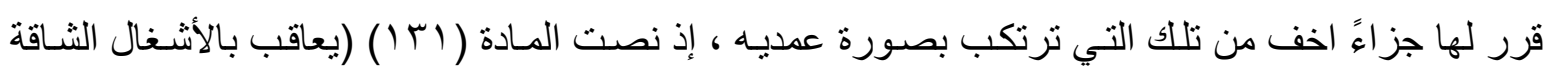

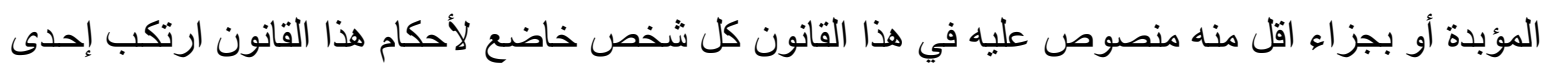


الجر ائم الآتيـة ا ــ إتيانـه فعلاً أو سلوكاً ممـا نص عليه في المـادة السـابقة بطريق الخطـأ أو الإهمال أو عدم الاحتياط أو التقصير ـ r - تسهيله بتقصيره أو إهماله أو عدم احتياطه أو خطئه ارتكاب الجر ائم المنصوص الته

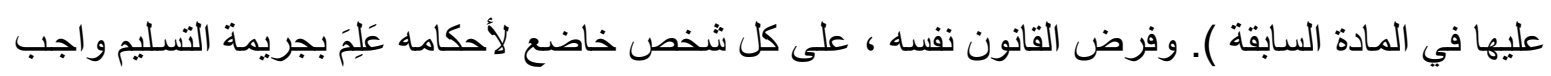

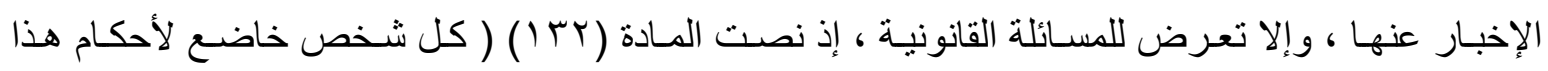

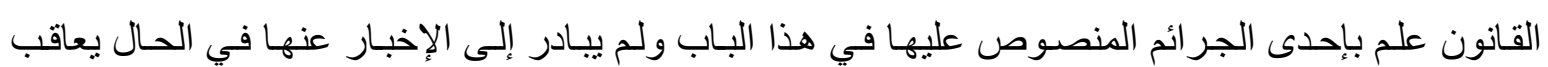
بالإعدام أو بجز اء اقل منه منصوص بإهول عليه في هذا القانون ) .

وسار قانون الجرائم والعقوبات العسكري اليمني رقم ( (Y) لسنة 19919 على ذات النهج ، إذ نصت مادة (0 10) ( يعاقب بالإعدام أو بجز اء يتتاسب مع نتائج الجريمة كل من أرتكب بقصد الخيانة أحدى الجرائم

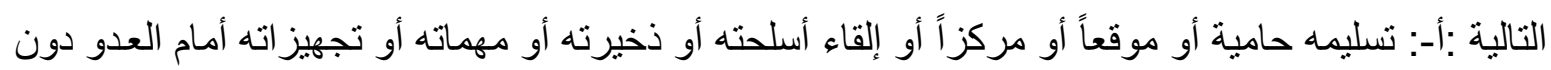
سبب قاهر. ب: تسهيله دخول العدو إقليم الجمهورية أو تسليمه مدناً أو حصوناً أو منشـآت أو مواقع أو موانئ

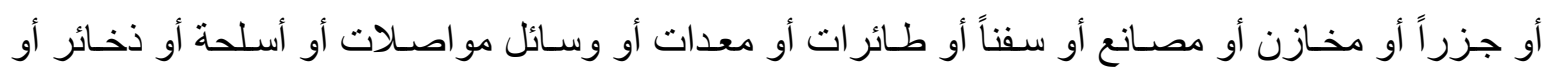
مهمات حربية أو مؤناً أو أغذية أو أدوية أو غير ذلك مما أعد للدفاع أو مما يستعمل في ذلك بدون أن يستنفا جميع وسائل الدفاع التي لديه وبدون أن يعمل بكل مايقتيه الواجب و الثـرف. و :تسليمه للعدو جنوداً ممن

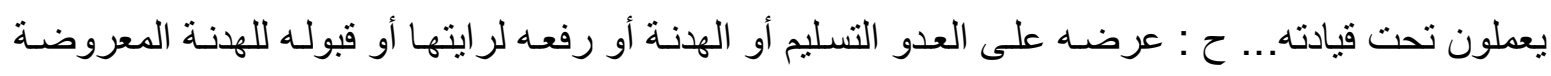
عليه عن طريق الخيانة أو بدون أن يكون لديه سلطة قانونية لإجر اء ذلك أو بدون أمر صريح....) ،و عاقب إنبه

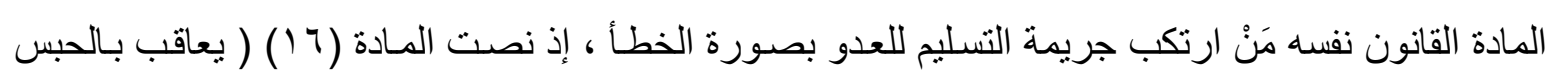

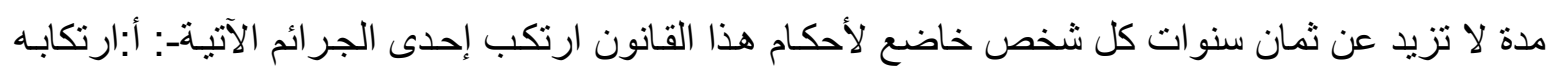

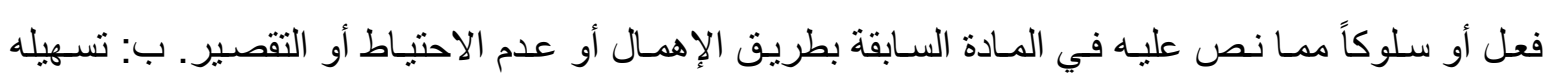

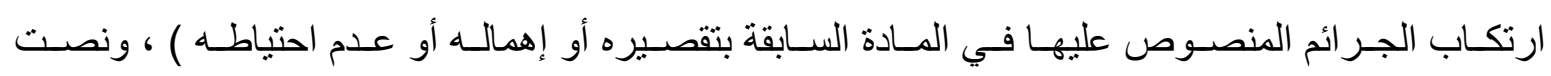
المادة(V V ) على عقوبـة ( كل شخص علم بإحدى الجرائم المنصوص عليها في هذا الفصل ولم يبـادر دون عذر مقبول إلى الإخبار عنها يعاقب بالحبس مدة لا تزيد على سنة أو بجز اء أقل منـه منصوص علئ عليه فئ في هذا القانون ) .

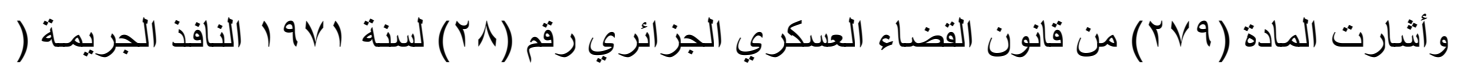

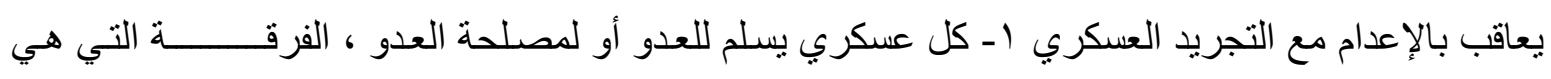

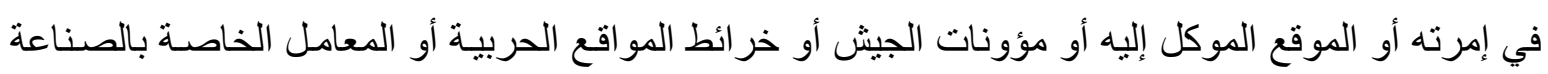

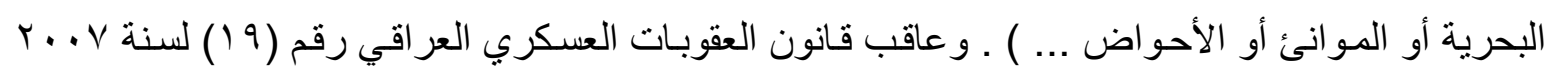

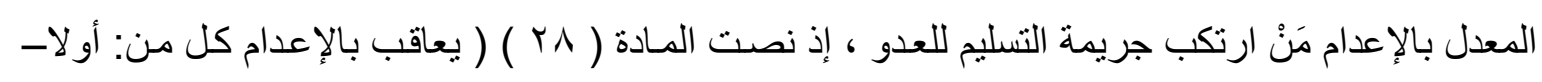

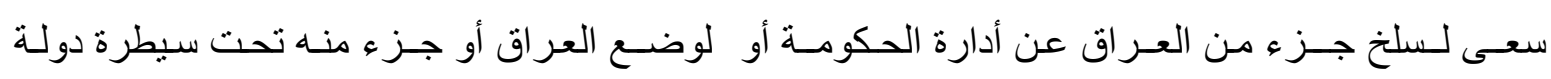

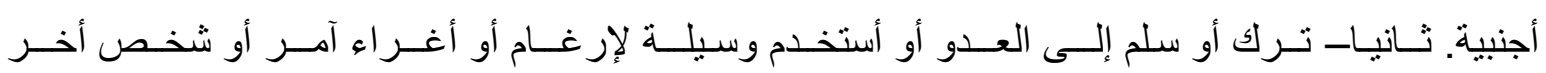

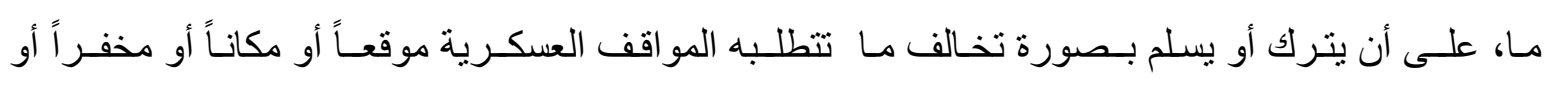

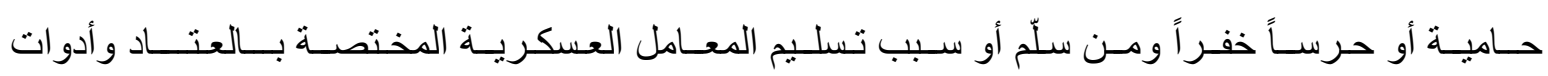




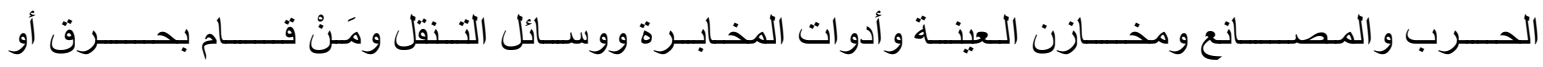

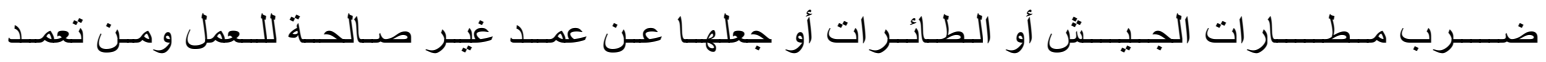

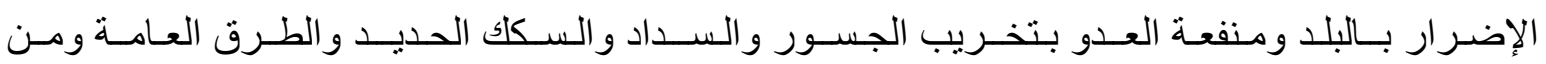

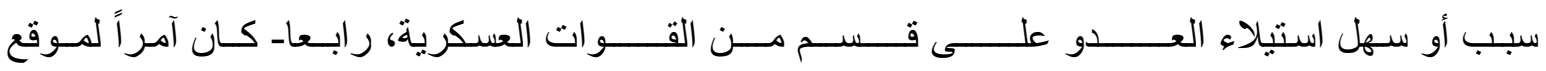

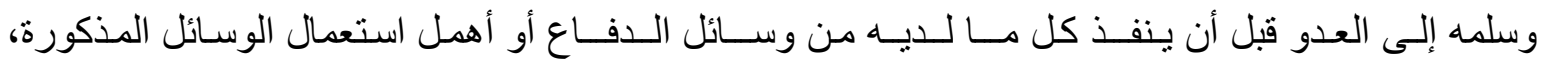

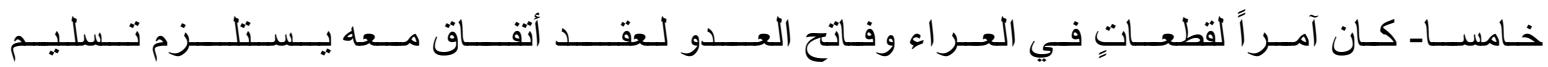

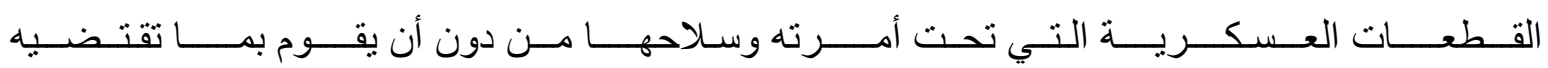

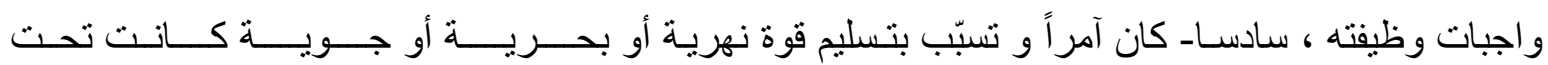

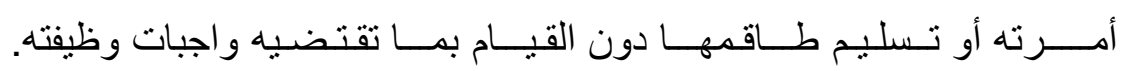

ولم يفرّق القانون أعلاه في العقوبة بين ارتكاب الجريمة عمداً أو إهمالاً ، ويلحظ ذلك من نص المـادة

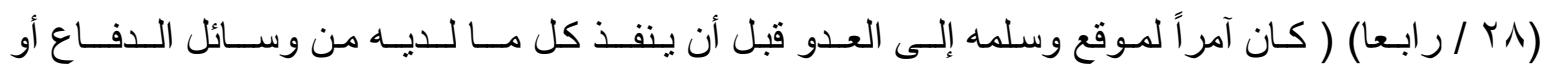

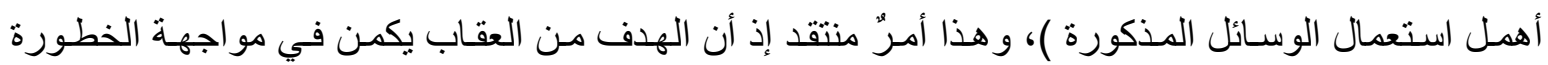

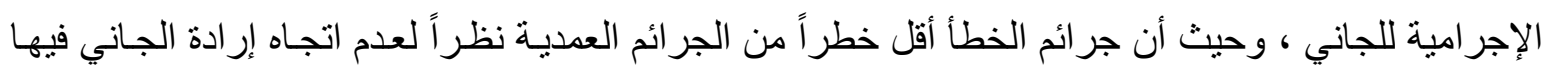

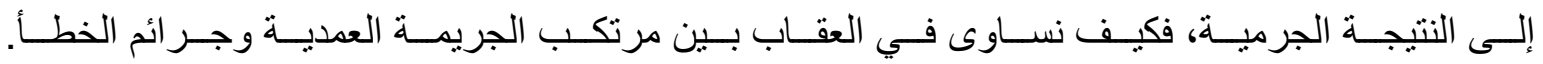
و أثشار القانون آنف الذكر إلى حالة إعفاء الثريك من العقوبة، إذ نصت المـادة (بr) ( يعفى الثريك من

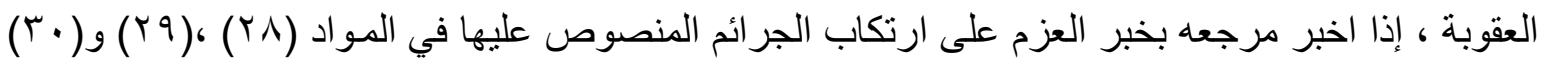

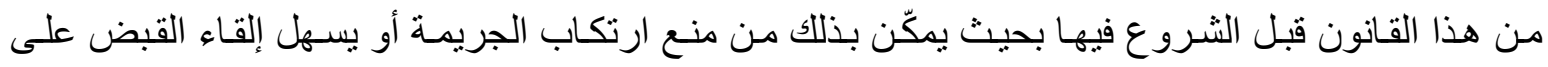
المشتركين فيها) ، يُفهم من هذا النص أن قانون العقوبات العسكري العر اقي قد أعفى من العقاب الثـريك

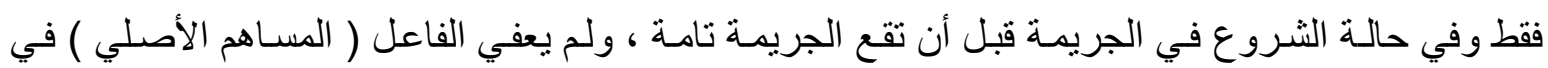
الجريمة من العقاب ، و هذا مسلك محمود لأنها يتفق مـع المبادئ العامـة في قانون العقوبـات في التشريعات الحديثة ، إذ أن جريمة التسليم للعدو لا يتحقق فيها الثـروع للفاعل (المسـاهم الأصلي) للجريمـة فهي إمـا تقع تامة أو لاتقع (ro).

\section{|لخاتهة:}

بعد أن فر غتُ من دراسة جريمة التسليم للعدو ، حَقَّ عليَّ تسجيل أهم مـاتوصلت إليه من استتناجات

ا - جريمة التسليم للعدو من الجرائم العسكرية التي تحتل أهمية كبيرة في قو انين العقوبـات العسكرية كافة، القديمة منها و الحديثة ، لما تنطوي عليه هذه الجرائم من خطر ولما يترتب على ارتكابها من نتائج جسيمة يمكن أن تهدد سلامة أر اضي الدولة و استقلالها. ז- إن المعنى القانون لجريمة التسليم وضـع الثـيء في حيازة العدو أو تمكينه من الاستيلاء عليه ، ويكون التسليم المقصود في القانون حاصلاً للعدو ، أو لأحد ممثليه من العسكريين أو المدنيين أو إلى أي شخص آخر 


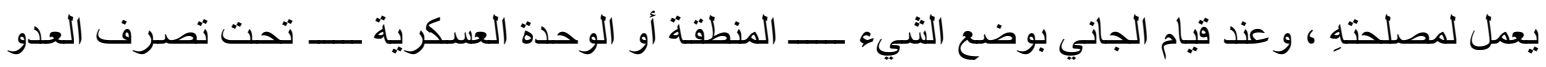
أو مكَّنُهُ من حيازته، فقد تمت الجريمة ، بصرف النظر عما إذا كان العدو قد انتفع بالثيء فعلاً أو لم ينتفع rـ تتكون جريمة التسليم للعدو من شرطين مفترضين يتجسد بمحل الجريمة، والثاني يشمل عدم استنفاذ جميع وسـائل الدفاع ، ويُقصـد بمحل الجريمـة الموقع أو المحل الذي يختص الجـاني بالمحافظة ، و الثـرط الثاني المفترض في جريمة التسليم الذي نصّت عليه القو انين موضوع المقارنـة هو أن بستنفذ العسكري فبل التسليم

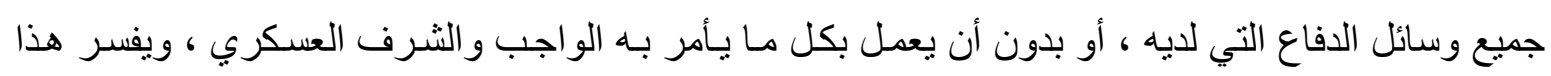
الثرط بأن على الجندي في ساحة التتال أن يو اجه خطر الموت حتى استتفاذ كافة وسائل الدفاع ، فلا يمكن لـه له أن يتذرع بحالة الضرورة . ع - تشترط القو انين العسكرية في مرتكب الجريمة أن يكون عسكرياً مكلفاً بالدفاع عن وحدته في زمن الحرب ومن ثم جرت غالبية التشريعات على الاكتفاء بالصفة العسكرية والقيادة الفعلية . هـ - إن جريمـة التسليم شـأنها شـأن أغلب الجرائم ، يتوجب لقيامها توافر أركانها ، و أولها الركن المـادي ،

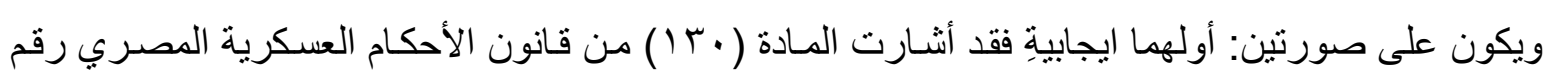

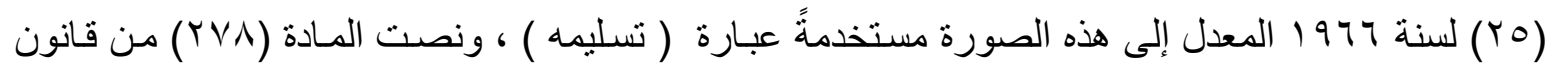

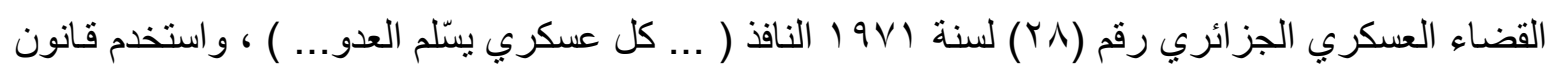

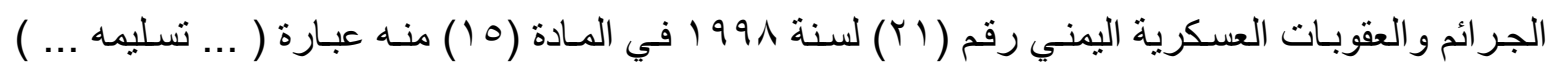

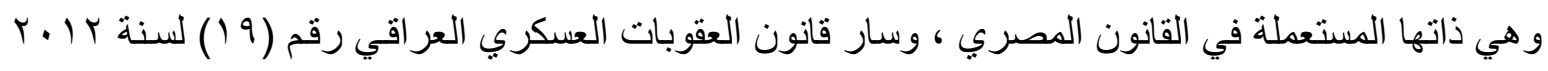

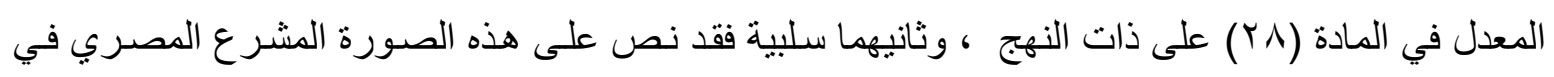

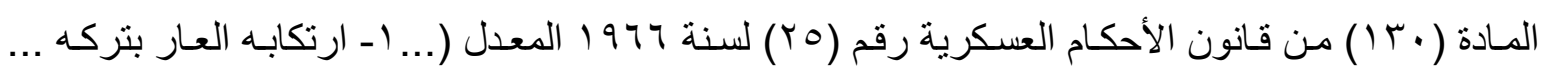
حامية أو محلاً أو موقعاً أو مركزاً . بـ ارتكابه العـار بإلقاء أسلحته أو ذخيرتـه أو مهاماته أو تجهيز اتهـ أمسام

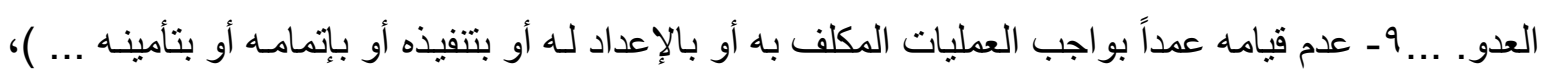

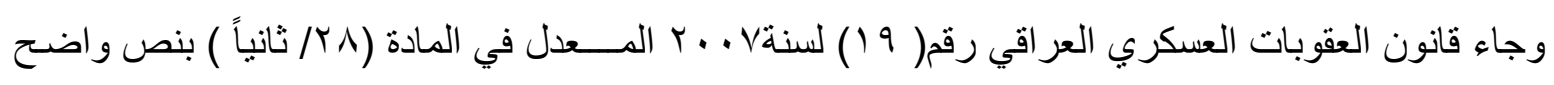
يشير إلى هذه الصورة (... ثانياً : ترك ... إلى العدو ... موقعاً أو مكاناً أو مخفراً ...) ، ولم يورد قانون

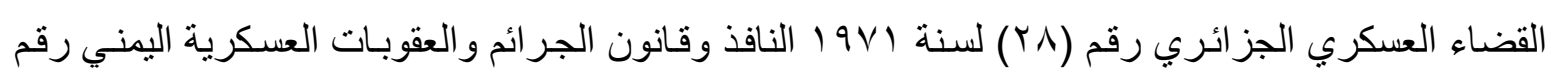

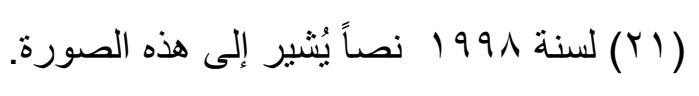

7- يتمثل الركن المعنوي في جر ائم (التسليم) العمديـة بالقصد ألجرمسي أو الجنائي ، في حين يكون بصورة

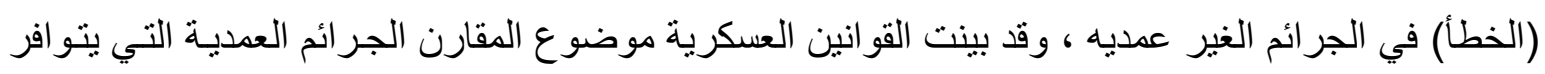

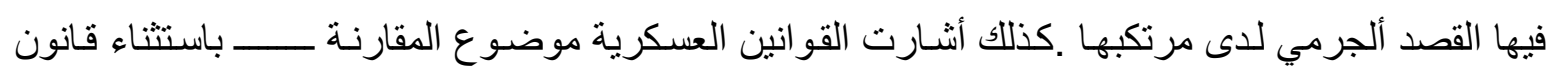

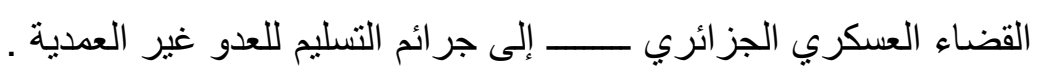

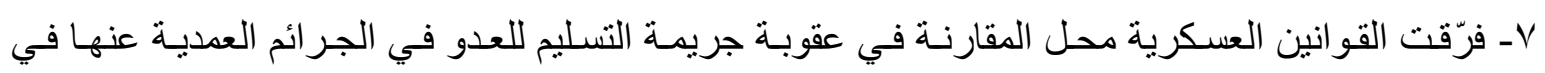

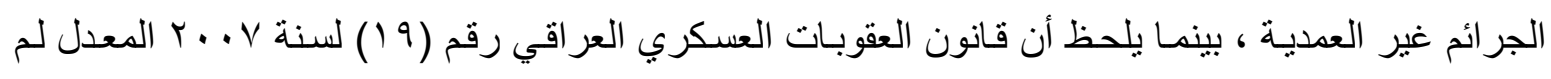
يفرق في العقوبة بين ارتكاب الجريمة عمداً أو إهمالاً. 
ثانيك: الاقترحات

ا ـ أدعو المشرع الجنائي العر اقي إلى إفر اد فصل خـاص بهذه الجريمـة تحت عنوان (جرائم التسليم للعدو )

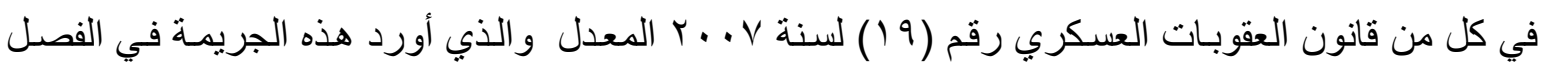
الثالث ضمن الجر ائم الماسة بأمن الدولة ، وكذلك قي قانون عقوبات قوى الأمن الداخلي العر اقي رقم (ع ( )

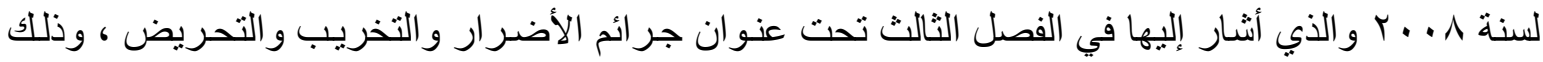
لرفع تناقض الحاصل في سياسة المشرع الجنائي العسكري العراقي .

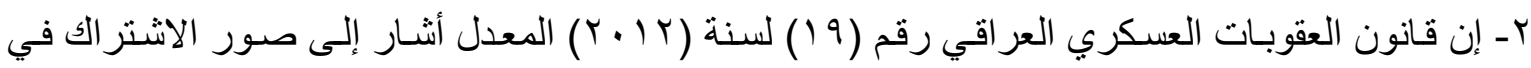
الجريمة عن طريق التحريض والمساعدة ، ولكنه لم ينص على أن من قام بـالتحريض و المسـاعدة يُعْْ شريكاً في الجريمة، بل عده فاعلاً لها، ويفهم ذلك من صدر المادة (^^) ( ... كل مَنْ ) ، وفي هذا مخالفة للمبادئ

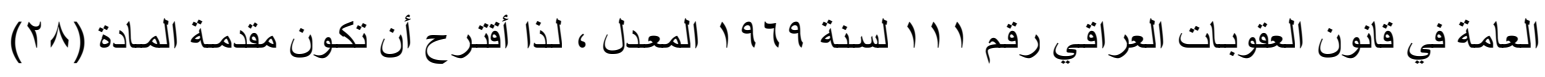
كالآتي ( ... كل مَنْ ساهم بوصفه فاعلاً أو شريكاً...).

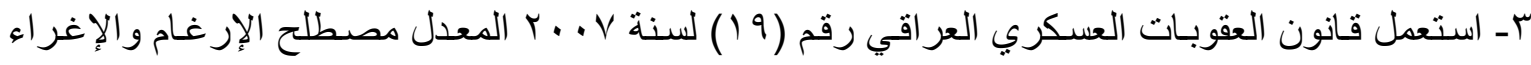

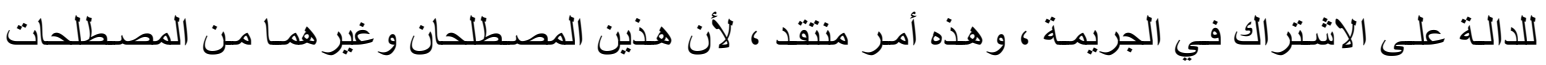
كالوعد والوعيد ، و الهـية ...الخ كلها تندرج في إطلار صور التحريض على ارتكاب الجريمـة ، والمصطلح الأخير أوسع واشمل لحالات لاتنظوي تحت المصطلحين الآخرين ، لذا اقترح أن تكون صياغة الفقرة ثانيا

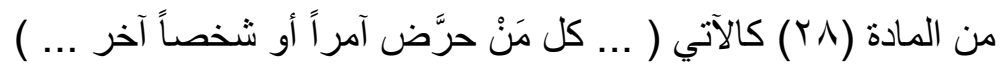
عـ قد يكون الثريك في جريمة التسليم للعدو ممن لا يحمل الصفة العسكرية ، فقد يكون مسؤو لاً في الدولة،

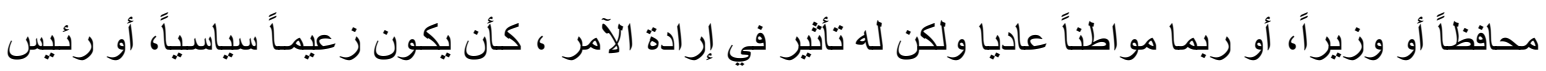

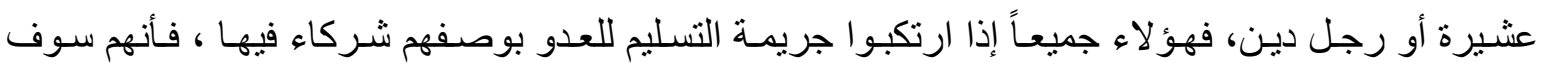

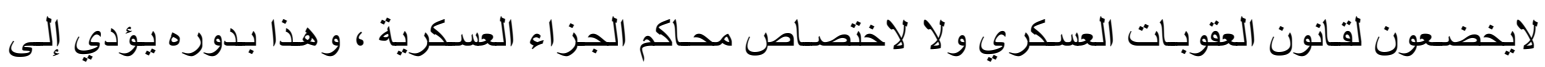
إربالك المحاكمات التي تجري بحق مرتكبي هكذا جر ائم إذ أن الفاعل سيخضـع للمحاكم العسكرية و الثـريك سيخضع للمحاكم المدنية على اعتبار ان كل من المحكمنين تدفع بعدم الاختصـاص النوعي ، لذا اقترح أن

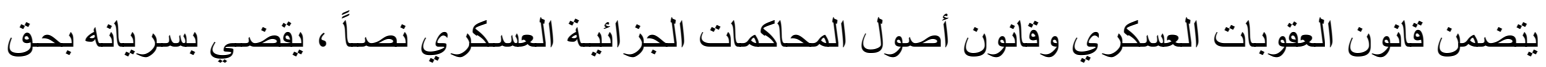
(كل شخص بوصفه فاعلا أو شريكاً ارتكب إحدى الجر ائم المنصوص عليها في القانونين ) . 0ـ اقترح على الجنـائي العسكري العر اقي يفرّق في قـانون العقوبـات العسكري العر اقي رقم (9 (1) لسـنة V . . . المعدل في العقوبة بين ارتكاب الجريمـة عمداً أو إهمالاً ، إذ أن جر ائم الخطأ أقل خطر اً من الجرائم

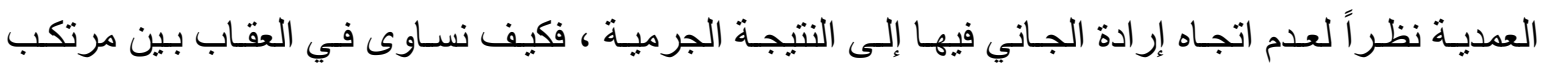
الجريمة العمدية وجر ائم الخطأ. 
(T) ينظر: د. محمود محمود مصطفى ، المصدر السابق ، صع ז ا.

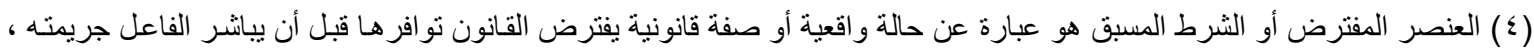

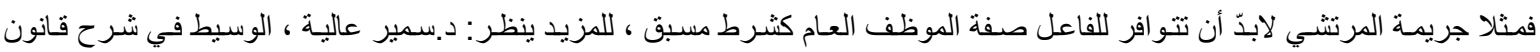

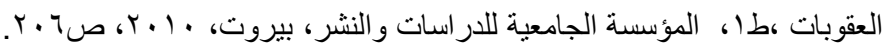
(0) بعض الكتاب لم يشترط لقيام الجريمة وجود أركانها العامة و الخاصة و إنما حددها على أساس وجود منطلبات موضوعية و أخرى معنوية،

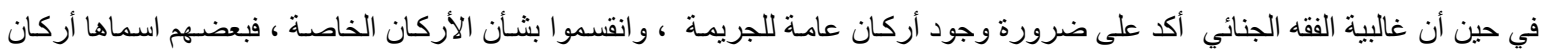

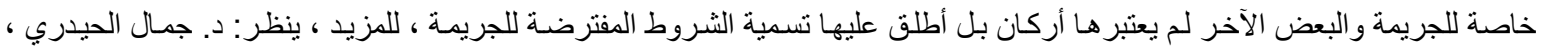

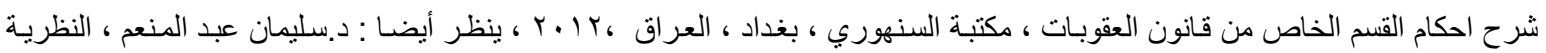

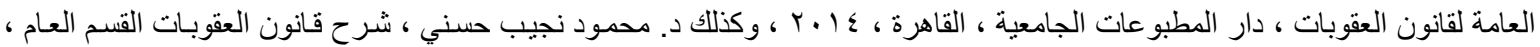

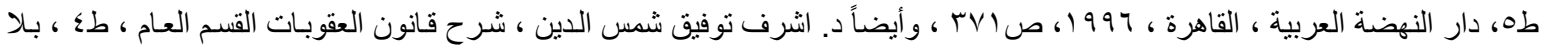

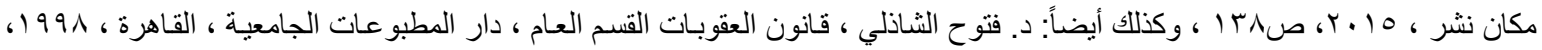

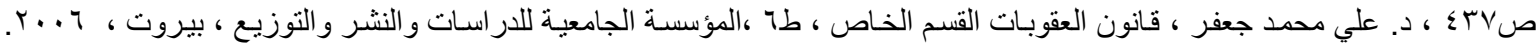

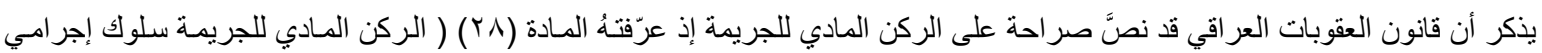
بارتكاب فعل جرمه القانون أو الامتتاع عن فعل أمر به القانون ) ، ونص القانون كذلك على الركن المعنوي للجريمة العمدية والذي يتخذ فيها

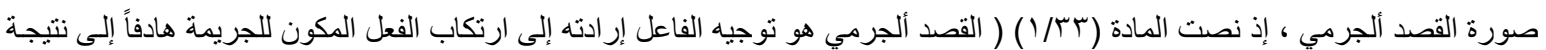

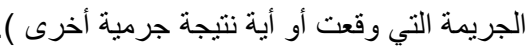

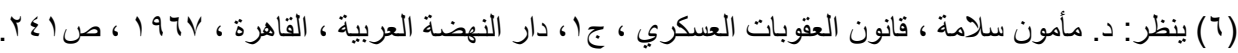
تعتبر حالة الضرورة في القانون الوضـعي مجرد مـانع من موانع المسؤولية الجنائيسة. ويتضـح هذا التكييف من صياغة النصوص التي

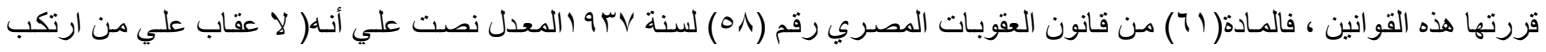
جريمة ألجأته إلي ارتكابها ضرورة وقاية نفسه أو غيره من خطر جسيم علي النفس علي وشك الوقوع بـه أو بغيره ولم يكن لإرادته دخل في

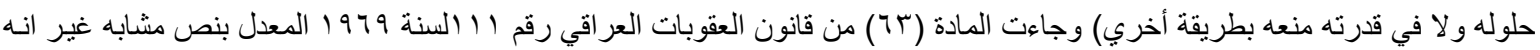
استعمل مصطلح ( لا يُّنسأل جنائياً) و اشترط أيضا أن يقع الخطر على النفس أو المال ، ذلك أن استعمال القانون المصري تعبير (لا عقاب) و القانون العر اقي استخدم مصـلح (لا يُسـأل جنائيـاً)هو التعبيـر الذي يستعمل عـادة في موانـع المسؤولية الجنائيـة، في حين أن القـانونين

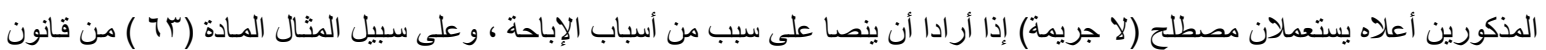

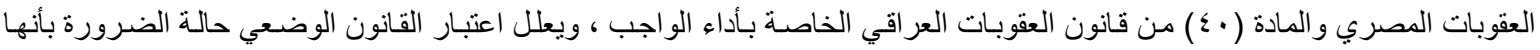

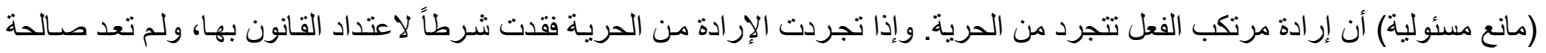

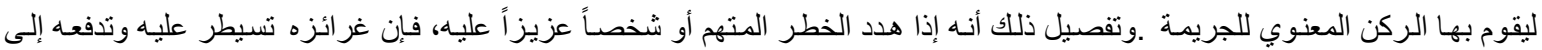

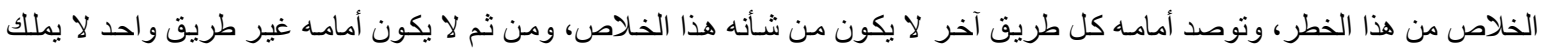
اختيار سواهو إذا هدد الخطر شخصاً لا تربطه بمرتكب الفعل صلة كالطبيب الذي يقضي على الجنين إنقاذاً للأم، أو من برى شخصـاً تحاصره

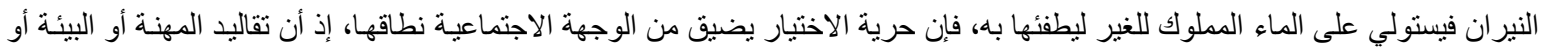

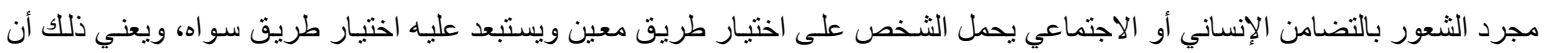

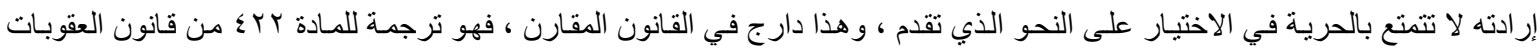

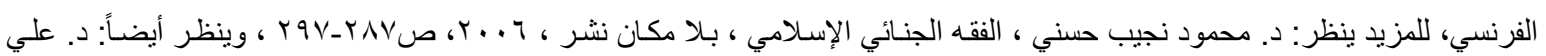

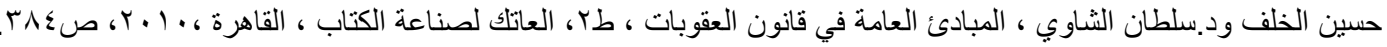

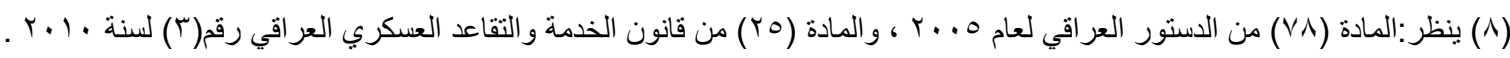
(9) حدد قانون العقوبات العر اقي رقم 1111 للسنة 1979 المعدل في مادة (1) ) منه صور الاشتر الك بالجريمة بالتحريض و الاتفاق والمساعدة

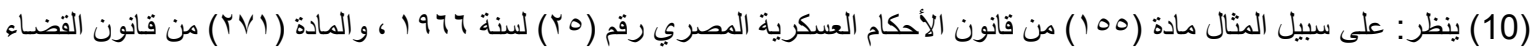

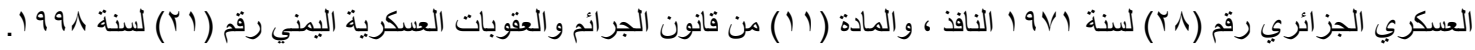

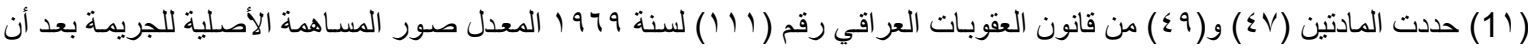




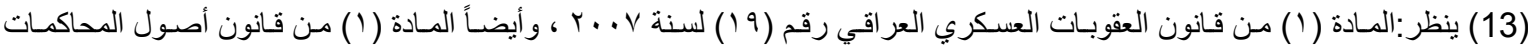

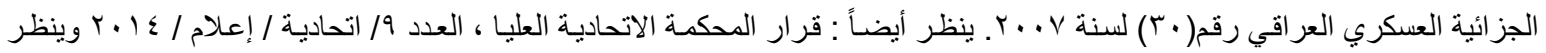

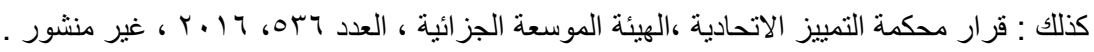
( ا () على الرغم من أن قو انين العقوبات اعتبرت الركن الثرعي (القانوني) من الأركان المكونة للجريمة ، فأن غالبية فقهاء القانون الجنائي يعتبرون الجريمة مكونة من ركنين احدهما مادي والآخر معنوي ، وبالر غم من ذلك فأني لم أهمل معالجة موضوع الركن الثرعي بل تطرقت

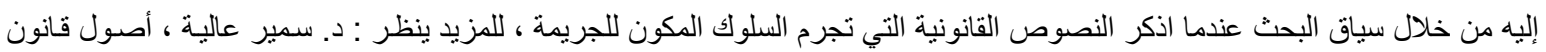

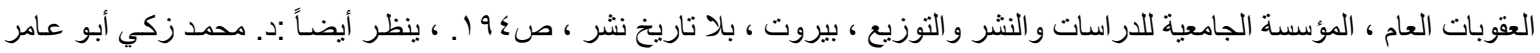

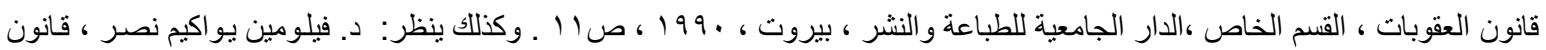

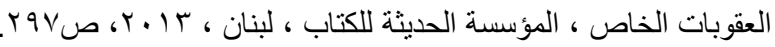

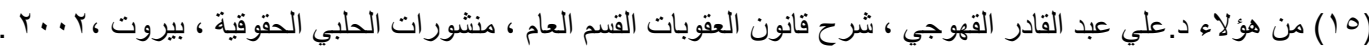

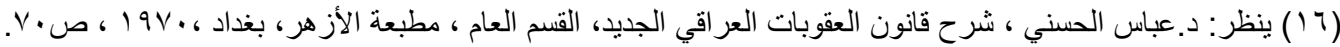

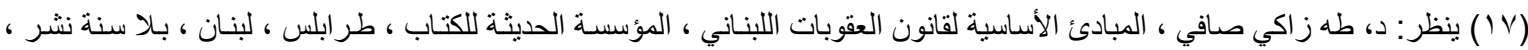

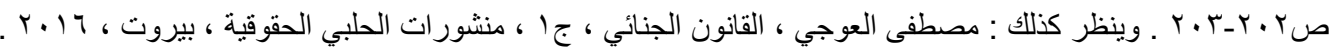

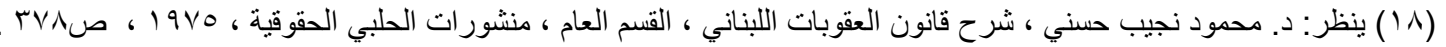

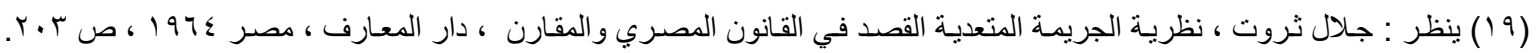

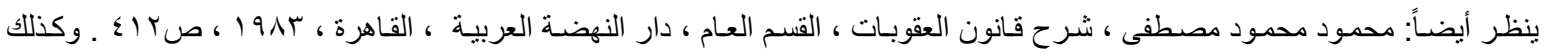

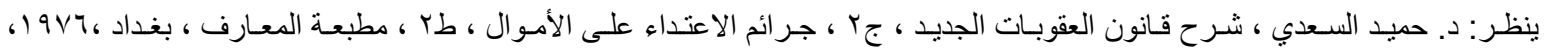

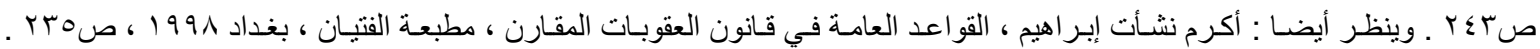

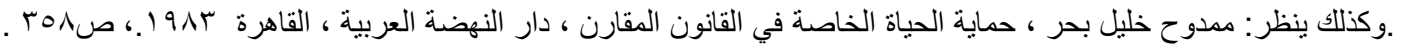

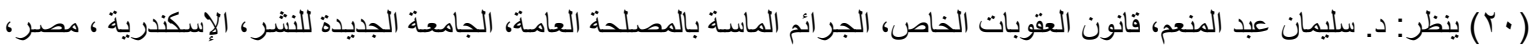

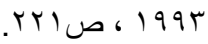

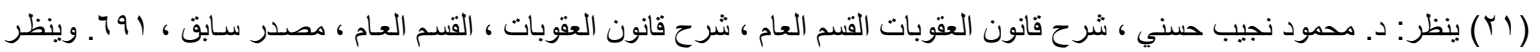

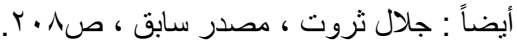

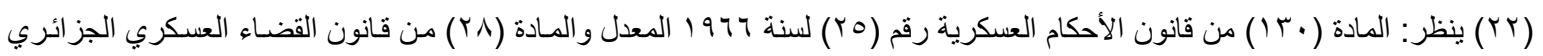

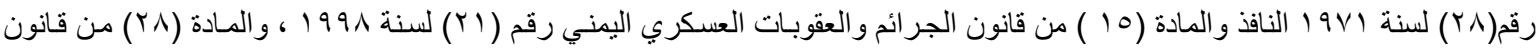

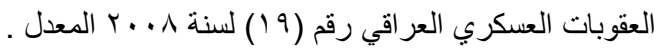

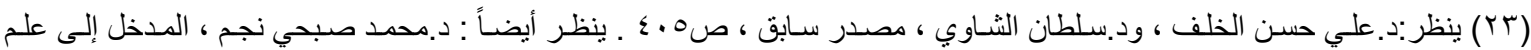

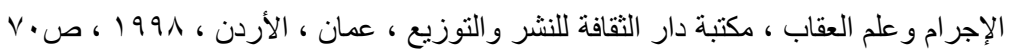

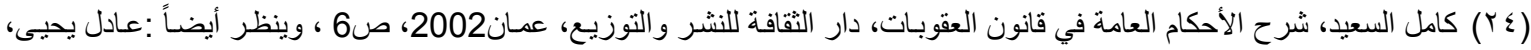

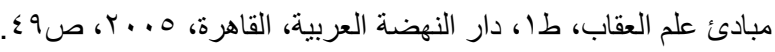
(Yo) لا يتحقق الثروع للفاعل في جريمة التسليم للعدو ، فالجريمة أما أن تقع تامـة أو لا تقع ، إذ أنها من جر ائم الخطر شـأنها شـأن جريمـة

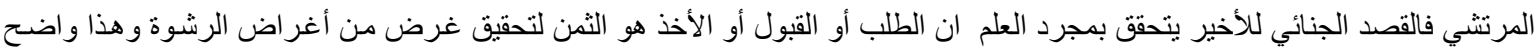

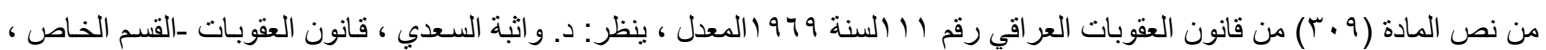

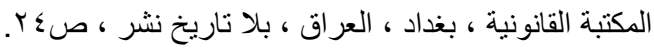

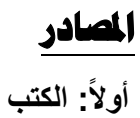

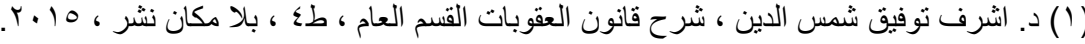

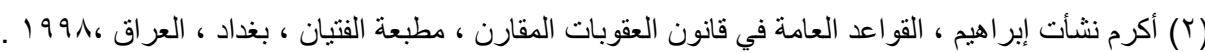

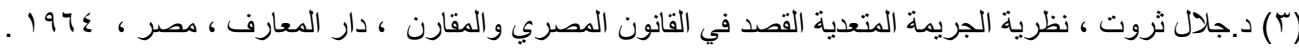

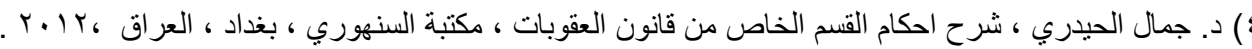

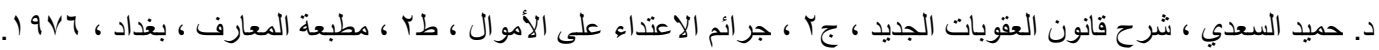




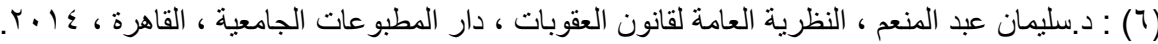

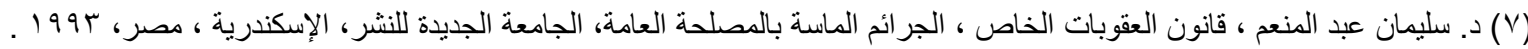

(^) د. سمير عالية ، أصول قانون العقوبات العام ، المؤسسة الجامعية للار اسات والنشر و التوزيع ، بيروت ، بلا تاريخ نشر .

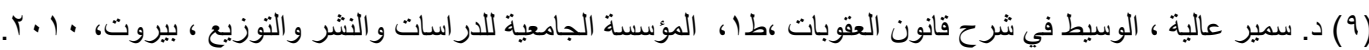
( • ( ) د. طه ز اكي صافي ، المبادئ الأساسية لقانون العقوبات اللبناني ، المؤسسة الحديثة للكتاب ، طر ابلس ، لبنان ، بلا سنة نشر .

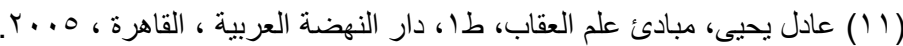

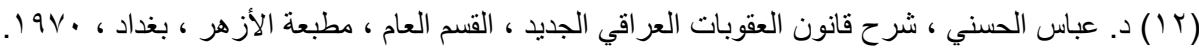

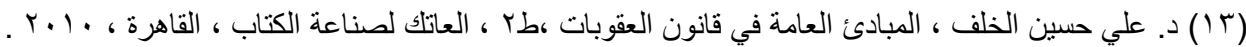

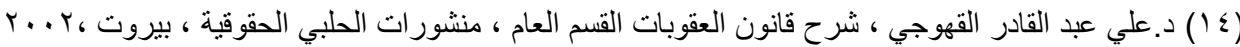

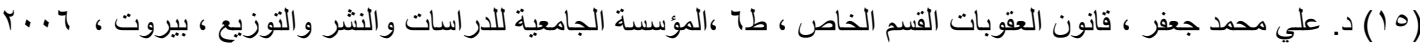

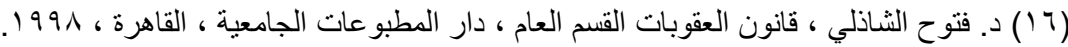

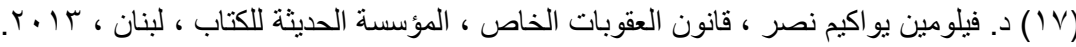

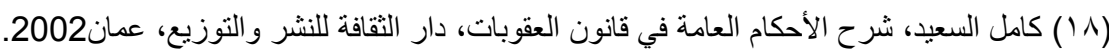

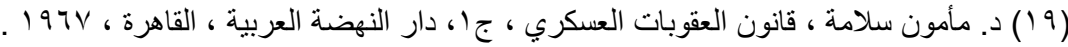

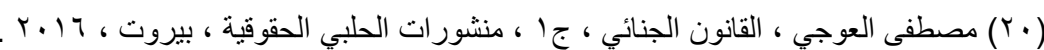

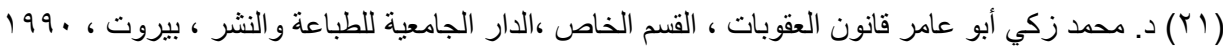

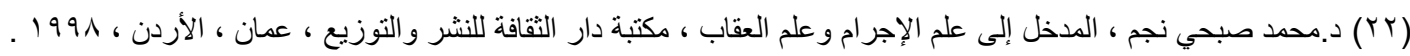

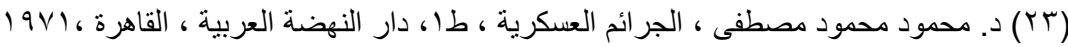

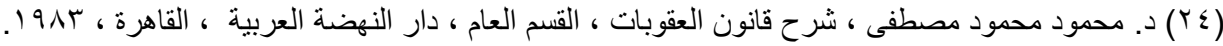

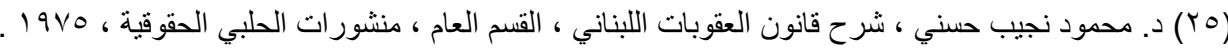

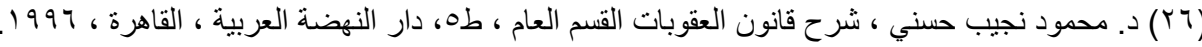

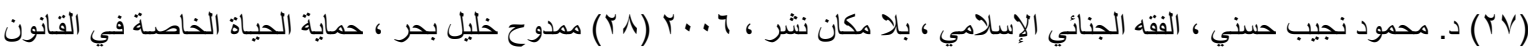

المقارن ، دار النهضة العربية ، القاهرة بهـ19.

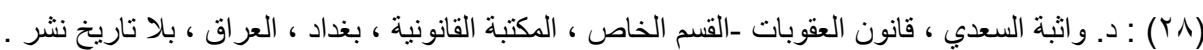

تانياً: الاساتير والقوانين

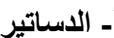

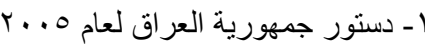

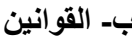

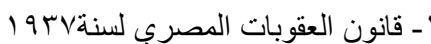

r-قانون الاحكام العسكرية المصري لسنة 1977

r- قانون العقوبات العر اقي لعام9 979

ـ ـ قانون القضاء العسكري الجزائري لسنة |

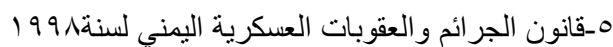

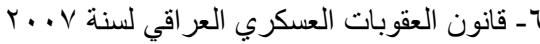

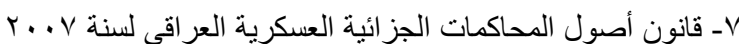

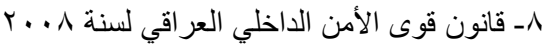

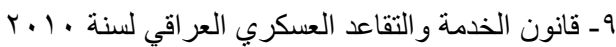

ثالثاً: القرارات القضائية

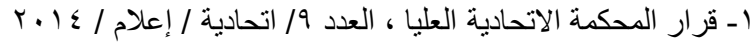

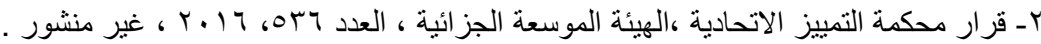

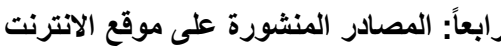

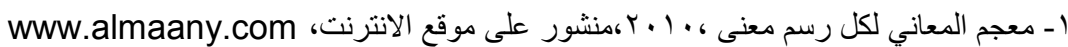

